\title{
Um discurso edificante de Søren Kierkegaard
}

\author{
Alvaro L. M. Valls
}

O pensador, escritor religioso, filósofo e psicólogo Søren Kierkegaard, que nasceu e morreu na capital da Dinamarca (1813-1855), produziu dezenas de obras atribuídas a pseudônimos que ia criando, mas ao mesmo tempo, paralelamente, publicou também dezenas de Discursos Edificantes, textos com aproximadamente vinte páginas cada um, nos quais, a partir de uma passagem bíblica, argumentava ("sem autoridade eclesiástica") buscando orientações para a existência concreta de cada indivíduo particular (pois "a multidão é a mentira").

Em 1847, além de As Obras do Amor (já traduzido: Editora Vozes), publicou também o volume Discursos Edificantes em Diversos Espiritos, dividido em três seções. Na primeira, um longo discurso que se costuma chamar "Pureza de Coração". $\mathrm{Na}$ segunda seção, três discursos sobre "O que aprendemos dos lírios do campo e das aves do céu” (sendo o primeiro mais poético ou estético, o segundo ético e o terceiro religioso). A terceira seção traz sete discursos intitulados "O Evangelho

1 Alvaro Luiz Montenegro Valls, natural de Porto Alegre, RS (1947), fez Mestrado (sobre Adorno, 1977) e Doutorado (sobre Kierkegaard, 1981) em Filosofia na Universidade de Heidelberg, Alemanha, orientado por Michael Theunissen. - Aposentado da UFRGS, atualmente Professor Titular de Filosofia da UNISINOS, São Leopoldo, RS. - Estágios de estudos na França e nos EUA. - Pesquisador do CNPq; orientou dissertações e teses; presidiu a ANPOF (2007-2008). - Publicou, entre outros livros: O que é Ética; Entre Sócrates e Cristo; Kierkegaard, cá entre nós; O Crucificado encontra Dionísio. - Traduziu, do alemão: Carl Schmitt (O Conceito do Político), J. Habermas (Dialética e Hermenêutica) e Th. W. Adorno (Kierkegaard. Construção do Estético) e, do idioma dinamarquês, Søren Kierkegaard: O Conceito de Ironia, Migalhas Filosóficas, As Obras do Amor, O Conceito de Angústia e os dois volumes do Pós-escrito às Migalhas Filosóficas. - Revisou, sempre auxiliado por Else Hagelund, a tradução do romance Niels Lyhne, de J. P. Jacobsen. - Traduz agora os Discursos Edificantes de 1847, de Kierkegaard (sobre Os lírios do campo e as aves do céu, e o Evangelho do sofrimento). 
dos Sofrimentos". O texto que aqui apresentamos é o primeiro da segunda seção. Ele insiste na ideia de que há muita glória em contentar-se em ser um ser humano, confiando em Deus. Os dois seguintes enfatizarão o valor positivo do trabalho e a importância de não idolatrar o dinheiro.

Estes discursos penetraram na filosofia graças aos conceitos de preocupação e de angústia. Embora K. Jaspers e M. Heidegger falem muito do "cuidado" (cura em latim, Sorge em alemão), tanto quanto tratam da "angústia" (Angst em alemão e dinamarquês), a palavra central do discurso que aqui traduzimos é "preocupação" (Bekymring em dinamarquês), a qual, não sendo apenas racional, mas também bastante emocional, vale em princípio como um sinônimo exato de nosso vocábulo "aflição". Kierkegaard se dirige, pois, ao homem aflito, preocupado, sobrecarregado pelas preocupações econômicas (aliás, nas vésperas da publicação do "Manifesto Comunista"), ou simplesmente pelas aflições relacionadas com o sustento, com o alimento e com o dia de amanhã - enfim, pela preocupação temporal. Apela, então, para a passagem do Sermão da Montanha, núcleo do Evangelho e do espírito franciscano, que aponta os lírios e as aves como nossos mestres inconscientes. Um detalhe linguístico: Sorgen, em dinamarquês, não é a mesma coisa, mas significa "a tristeza/o luto". Não confundir, portanto.

Esperamos publicar em breve (Editora LiberArs) os dez discursos que compõem a segunda e a terceira seções deste volume de 1847. Esta tradução aqui apresentada (com notas de rodapé ilustrativas) guarda ainda traços que poderão vir a ser lapidados ou burilados, embora já confiemos na fidelidade ao seu conteúdo e ao espírito do autor.

Porto Alegre, abril de 2017. 


\section{Hva vi lære af Lilierne paa Marken og af Himmelens Fugle}

Soren Kierkegaard

\section{I}

\section{Dette hellige Evangelium skriver Evangelisten Matthæus, 6. Cap. 24 Vers til Enden}

Ingen kan tiene to Herrer; thi han maa enten hade den ene og elske den anden, eller holde sig til den ene og foragte den anden. I kunne ikke tiene Gud og Mammon. 25. Derfor siger jeg Eder! bekymrer Eder ikke for Eders Liv, hvad I skulle æde, og hvad I skulle drikke; ikke heller for Eders Legeme, hvad I skulle iføres. Er ikke Livet Mere end Maden, og Legemet Mere end Klæderne? 26. Seer til Himmelens Fugle; de saae ikke, og høste ikke, og sanke ikke i Lader, og Eders himmelske Fader føder dem; ere I ikke meget Mere end de? 27. Men hvo iblandt Eder kan lægge en Alen til sin Væxt, endog han bekymrer sig derfor? 28. Og hvi bekymre I Eder for Klæderne? Betragter Li lierne paa Marken, hvorledes de voxe; de arbeide ikke, spinde ikke. 29. Men jeg siger Eder, at end ikke Salomo $i$ al sin Herlighed var saa klædt, som een af dem. 30. Klæder da Gud saaledes det Græs paa Marken, som er i Dag, og i Morgen kastes i Ovnen, skulde han ikke meget mere klæde Eder, I lidet troende! 31. Derfor skulle I ikke bekymre Eder, og sige: hvad skulle vi æde? eller: hvad skulle vi drikke? eller: hvormed skulle vi klæde os? 32. efter alt saadant søge Hedningerne; thi Eders himmelske Fader veed, at I have alle disse Ting behov. 33. Men søger først Guds Rige og hans Retfærdighed, saa skulle og alle disse Ting tillægges Eder. 34. Bekymrer Eder derfor ikke for den anden Morgen; thi den Dag imorgen skal bekymre sig for sit Eget. Hver Dag haver nok i sin Plage.

Hvo har ikke kjendt dette hellige Evangelium fra sin tidligste Barndom, og ofte glædet sig ved det glade Budskab! Og dog er det ikke saaledes ligefrem et glad Budskab; det har en væsentlig Egenskab, der ret egentligen gjør det til et Evangelium, den nemlig, at det henvender sig til Bekymrede; $j a$, i hver en Linie af det bekymrede Evangelium er det kjendeligt, at Talen ikke er til de Karske, ikke til de Stærke, ikke til de $\mid$ Lykkelige, men til de Bekymrede; o, det er saa kjendeligt, at det glade Budskab selv gjør, hvad det siger Gud at gjøre, antager sig de Bekymrede og haver Omsorg for dem - paa den rette Maade. Ak, dette gjøres vel fornødent, thi Enhver der har Sorg, og især jo dybere og jo længere den trænger ind i Sjelen, eller jo længere den trænger dybt derind, han fristes maaskee ogsaa til utaalmodigt ikke at ville høre menneskelig Tale om Trøst og Haab. Maaskee har den Sørgende Uret, maaskee er han for utaalmodig, naar det forekommer ham saa, at intet 
Menneske kan tale ham hans Sorg tilpas; thi den Lykkelige forstaaer ham ikke; den Stærke synes netop idet han trøster at hæve sig over ham; den Bekymrede forøger ham kun Sorgen ved sit Tilskud. Naar saa er, bliver det altsaa bedst, at see sig om andre Lærere, hvis Tale ikke er Misforstaaelse, hvis Opmuntring ingen hemmelig Bebreidelse indeholder, hvis Blik ikke dømmer, hvis Trøst ikke hidser istedenfor at berolige.

Til saadanne Lærere henviser det bekymrede Evangelium den Sørgende: til Lilierne paa Marken og til Himmelens Fugle. Hos disse billige Lærere, hvilke man hverken betaler med Penge eller med Ydmygelser, er ingen Misforstaaelse mulig, thi de tie - af Omsorg for den Bekymrede. Og al Misforstaaelse fremkommer jo ved Talen, nærmere forstaaet derved, at Talen, især Samtalen, indeholder en Sammenligning, som naar den Lykkelige siger til den Bekymrede: vær glad, da indeholder Udsagnet tillige: som jeg er det; og naar den Stærke siger: vær stærk, da forstaaes under: som jeg er det. Men Taushed ærer Bekymringen og ærer den Bekymrede, som Jobs Venner, der de af Ærbødighed sadde tause hos den Lidende og holdt ham i Ære. Og dog, de saae jo paa ham! Men det, at det ene Menneske seer paa det andet, indeholder atter en Sammenligning. De tause Venner sammenlignede ikke Job med sig, dette skete først, da de brød Æren (hvori de tause holdt ham) og Tausheden, for med Taler at overfalde den Lidende; men deres Tilstedeværelse foranledigede Job til at sammenligne sig med sig selv. Saaledes kan nemlig intet $\mid$ Menneske være tilstede, om han end tier, at hans Tilstedeværelse sammenlignelsesviis slet Intet betyder. Dette kan i det Høieste et Barn, der jo ogsaa har en vis Lighed med Lilierne paa Marken og med Himmelens Fugle; hvor ofte har ikke en Lidende sandet og rørt fornummet, at naar kun et Barn er tilstede, er der dog ingen Tilstedeværende. Og nu Lilien paa Marken! Om den end rigeligt har sit Udkomme, den sammenligner ikke sin Velstand med Nogens Armod; om den end er sorgløs i al sin Deilighed, den sammenligner sig hverken med Salomo eller med den Usleste. Og om Fuglen end svinger sig let i Skyen, den sammenligner ikke sin lette Flugt med den Bekymredes tunge Gang; om Fuglen, rigere end Den der har Laderne fulde, end ikke sanker i Lade: den sammenligner ikke sin rige Uafhængighed med den Nødlidende, som sanker forgjæves. Nei, der hvor Lilien blomstrer deiligt - paa Marken, der hvor Fuglen frit er tilhuse - under Himlen, hvis Trøsten søges: der er uafbrudt Taushed, der er ingen Tilstedeværende, der er Alt idel Overtalelse.

Dog er dette jo kun saa, dersom den Sørgende virkelig giver Agt paa Lilierne og paa Fuglene, over dem og deres Liv glemmer sig selv, medens han i denne Selvfortabelse af dem, ved sig selv, uformærket lærer Noget om sig selv; uformærket, thi der er jo idel Taushed, ingen Tilstedeværende, den Bekymrede fritagen for enhver Medviden, undtagen Guds, sin egen - og Liliernes.

Lad os da i denne Tale betænke, hvorledes den Bekymrede, ved ret at see til Lilierne paa Marken og til Himmelens Fugle, lærer: 
at nøies med det at være Menneske.

»Betragter Lilierne paa Marken«, betragt dem, det vil sige læg nøie Mærke til dem, gjør dem til Gjenstand, ikke for et flygtigt Syn i Forbigaaende, men for Din Betragtning; derfor er der brugt det Udtryk, som Præsten pleier at bruge i den alvorligste og høitideligste Forbindelse, naar han siger, lader os i denne Andagtstime betragte Det og Det. Saa høitidelig er Opfordringen og Indbydelsen; Mangen lever maaskee i den store Stad og seer aldrig Lilierne; Mangen lever maaskee paa Landet, og gaaer dem dagligen ligegyldigt forbi: ak, hvor Mangen er der vel, der efter Evangeliets Anviisning ret betragter dem! - »Lilierne paa Marken«, thi der er ikke Tale om de sjeldne Planter, hvilke en Gartner opelsker i sin Have, og som betragtes af Kjendere; nei, gaae ud paa Marken, der hvor intet Menneske bærer Omsorg for de forladte Lilier, og hvor det dog er saa kjendeligt, at de ikke ere forladte. Skulde denne Opfordring ikke være indbydende for den Bekymrede, ak, han er jo ogsaa som den forladte Lilie, forladt, miskjendt, overseet, uden Menneskenes Omsorg, indtil han ved ret at betragte Lilien forstaaer, at han ikke er forladt.

Saa gaaer den Bekymrede ud paa Marken, og han standser ved Lilierne. Ikke som et lykkeligt Barn, eller en barnagtig Ældre vel gjør det, løber han om for at finde den smukkeste, for at tilfredsstille Nysgjerrigheden ved at finde den sjeldne. Nei, med stille Høitidelighed betragter han dem, som de staae der, i talrig, i broget Mængde, den ene lige saa god som den anden - »hvorledes de voxe«. $\mathrm{Nu}$, hvorledes de voxe, seer han egentligen ikke, thi det er jo som Ordsproget siger, at man ikke kan see Græsset groe, men han seer dog hvorledes de voxe, eller netop fordi det er ham ubegribeligt, hvorledes de voxe, seer han, at der maa være En, der kjender dem ligesaa nøie, som Gartneren kjender de sjeldne Planter; En, der dagligt seer til dem, Morgen og Aften, ligesom Gartneren seer til de sjeldne Planter; En, der giver dem Væxt. Formodentligen er det vel ogsaa den samme Ene, der giver Gartnerens sjeldne Planter Væxt, kun at disse saa let foranledige Misforstaaelse ved Hjælp af Gartneren. De forladte Lilier derimod, de almindelige Lilier, Markens Lilier, foranledige ikke Betragteren til nogen Misforstaaelse. Thi der, hvor Gartneren er synlig, der, hvor ingen Møie og ingen Bekostning spares for at drive Rigmandens sjeldne Planter frem, der synes det maaskee $\mid$ bedre at forstaae, at de voxe; men derimod paa Marken, hvor Ingen, Ingen, Ingen bekymrer sig om Lilierne, hvorledes kan de der voxe? Og dog voxe de.

Men saa maae vel de fattige Lilier selv arbeide desto strængere. Nei, »de arbeide ikke«; det er kun de sjældne Blomster, som der er saa meget Arbeide forbundet med, for at faae til at voxe. Der, hvor Teppet er kosteligere end i Kongernes Sale, der arbeides ikke. Idet Betragterens Øie forlystes og vederqvæges ved Synet, skal hans Sjel ikke bekymres ved Tanken om, hvorledes de stakkels fattige Lilier maae arbeide og trælle for at faae Teppet saa smukt. Kun i Forhold til menneskelig Kunstfærdigheds Frembringelse er det saaledes, at Øiet, medens det blændes ved Arbeidets Fiinhed, fyldes med Taarer ved Tanken om den stakkels Kniplerskes Lidelser. 
Lilierne »arbeide ikke, spinde ikke«, de bestille egentligen ikke Andet end at pynte sig, eller endnu rettere: at være pyntede. Som der i det Foregaaende af Evangeliet, hvor Talen er om Fuglene, naar der siges: »de saae ikke, de høste ikke, de sanke ikke i Lader«, ligesom hentydes til Mandens Arbeiden for at ernære sig og Sine: saaledes indeholde disse Ord om Lilierne (de arbeide ikke, spinde ikke) ligesom en Hentydning til Qvindens Arbeiden. Qvinden bliver ved Huset, hun gaaer ikke ud for at søge Livets Fornødenheder, hun bliver hjemme, syer og spinder, søger at holde Alt saa pynteligt som muligt: hendes daglige Syssel, hendes flittige Arbeiden staaer dog nærmest i Forhold til Pyntelighed. Saaledes Lilien ogsaa: den bliver ved Huset, den gaaer ikke af Stedet, men den arbeider ikke, den spinder ikke - den pynter sig blot, eller endnu rettere, den er pyntet. Skulde Lilien have nogen Bekymring, da vilde denne ikke være for Udkommet, som dog Fuglen kunde synes at have, siden den flyver saa vidt og bredt omkring og sanker Næring, nei, Liliens Bekymring maatte qvindeligt staae i Forhold til, om den nu ogsaa var deilig og var pyntet. Men den er uden Bekymring.

Thi pyntet er den, det er vist; ja, Betragteren kan ikke lade det være, han bøier sig ned til den enkelte Lilie, han tager den forste den bedste - »jeg siger Eder, at end ikke Salomo i al sin Herlighed var kladt som een af dem. "Saa betragter han den nøie og nærved, og om hans Sind var uroligt, ak, som et menneskeligt Sind kan være uroligt, og om hans Hjerte bankede heftigt, ak, som et menneskeligt Hjerte kan det, han slaaer sig ganske til Ro, blot for at betragte denne Lilie. Jo nøiere han seer, jo mere han forundres over dens Deilighed og dens sindrige Dannelse; thi kun i Forhold til menneskelig Kunstfærdigheds Frembringelser gjelder det, at man, ved at see meget nøie til, opdager Mangler og Ufuldkommenhed, det gjælder, at hvis Du skærper Dit Syn med det kunstigt slebne Glas, da seer Du selv i den fineste menneskelige Væv de grove Traade. Ak, det er, som om Mennesket til sin egen Ydmygelse, har gjort den Opdagelse, hvoraf han er stolt: da han opdagede at slibe Glasset kunstigt, saa det forstørrer Gjenstanden, da opdagede han, ved Hjælp af det forstørrende Glas, at selv det fineste menneskelige Arbeide er grovt og ufuldkomment. Men Opdagelsen, der ydmygede Mennesket, ærede Gud, thi aldrig har Nogen, ved Hjælp af det forstørrende Glas, opdaget, at Lilien blev mindre deilig, mindre sindrig, tvertimod viste den sig at være deiligere og deiligere, sindrigere og sindrigere. Ja Opdagelsen ærede Gud, som enhver Opdagelse maa det, thi kun i Forhold til en menneskelig Kunstner gjælder det, at Den, der kjender ham nøie, nærved og til daglig Brug, dog seer, at han ikke er stor; i Forhold til den Kunstner, som væver Markens Tæppe og virker Liliens Deilighed, gjælder det, at Forundringen stiger med Tilnærmelsen, at Tilbedelsens Afstand voxer med Tilnærmelsen til ham.

Saa staaer da den Bekymrede, som med sin Sorg gik til Lilierne, mellem dem paa Marken, forundret over Liliens Deilighed, som han betragter; han har taget den første den bedste, han har intet Valg gjort, det falder ham slet ikke ind, at der skulde være nogen eneste Lilie, saa lidet som noget Straa paa Marken, om hvilket det ikke gjaldt, at end ikke Salomo i al sin Herlighed var klædt som en af dem. Sæt Lilien $\mid$ kunde tale, skulde den da ikke sige til den Bekymrede: »hvi forundrer Du Dig saaledes over mig; skulde det, at 
være Menneske, ikke være lige saa herligt, skulde det ikke derom gjælde, at dog al Salomos Herlighed Intet er i Sammenligning med, hvad ethvert Menneske er, ved at være Menneske, saa Salomo for at være det Herligste han er, og være sig dette bevidst, maatte afføre sig al sin Herlighed og blot være Menneske! Skulde hvad der gjælder om mig Stakkel, ikke gjælde om det, at være Menneske, der jo er Skabningens Underværk! « Dog Lilien kan ikke tale, men netop fordi den ikke kan tale, netop fordi der er idel Taushed derude og ingen Tilstedeværende, netop derfor er den Bekymrede, hvis han taler og hvis han taler med Lilien, i det Tilfælde, at han taler med sig selv; ja lidt efter lidt opdager han, at han taler om sig selv, at det han siger om Lilien siger han om sig selv. Det er ikke Lilien, der siger det, den kan ikke tale; det er ikke noget andet Menneske, der siger det til ham, thi med det andet Menneske kommer dog saa let strax Sammenligningens urolige Tanke; blandt Lilierne er den Bekymrede kun Mennesket, og - nøiet med det at være Menneske. Thi ganske i samme Forstand som Lilien er Lilie, ganske i samme Forstand er han, trods alle sine Bekymringer som Menneske, Menneske; og ganske i samme Forstand, som Lilien, uden at arbeide og uden at spinde, er skjønnere end Salomos Herlighed, ganske i samme Forstand er ogsaa Mennesket, uden at arbeide, uden at spinde, uden nogen hans Fortjenstfuldhed, ved at være Menneske, herligere end Salomos Herlighed. Der staaer jo heller ikke i Evangeliet, at Lilien er herligere end Salomo, nei, der staaer, at den er bedre klædt end Salomo i al hans Herlighed. Ak, men i den idelige Omgang med Mennesker, i den mangfoldige Forskjellighed og dennes forskjellige Berøringer, glemmer man, ved den travle eller den bekymrede Sammenlignings Opfindsomhed, hvad det er, at være Menneske, man glemmer det over Forskjelligheden mellem Menneske og Menneske. Men paa Marken hos Lilierne, hvor Himlen hvælver sig høit - som over en Hersker, frit - som Aandedrættet er det derude, hvor Skyernes store Tanker adspreder al Smaalighed: der er den Bekymrede det eneste Menneske, og lærer af Lilierne, hvad han maaskee ikke kunde lære af noget andet Menneske.

»Betragter Lilierne paa Marken.« Hvor kort, hvor høitidelig, hvor ligelig er denne Tale om Lilierne; der er ikke Spoer af Anelse, der ymtes ikke det Mindste om, at der kunde være nogen Forskjel mellem Lilierne indbyrdes; der er talet om dem alle og om hver een eneste, der er talet ligeligt om dem alle: Lilierne. Maaskee vil En mene, at det dog ogsaa var besynderligt, og for meget forlangt, at det menneskelige Sprog skulde indlade sig paa Forskjelligheden mellem Lilierne indbyrdes og disses mulige Bekymringer, foranledigede ved Forskjelligheden; maaskee vil En mene: »saadanne Forskjelligheder og saadanne Bekymringer ere ikke værd at agte paa. «Lad os forstaae hinanden. Er Meningen denne, at det for Lilierne ikke er værd at agte paa saadanne Bekymringer, det er, at Lilierne burde være saa fornuftige, ikke at agte paa Sligt; eller er Meningen denne, at det er under Menneskets Værdighed, at bryde sig om Liliernes mulige Bekymringer, fordi nemlig Mennesket er Menneske og ikke Lilie. Dette vil sige: ere saadanne Bekymringer i og for sig selv ufornuftige, og derfor ikke værd at agte paa, ligegyldigt enten det er de enfoldige Lilier, eller de fornuftige Mennesker, som have dem; eller er den væsentligen samme Bekymring en anden, naar Lilien har den, end naar Mennesket har den, saa det er daarligt af Lilien at bekymre sig om 
Sligt, men ikke daarligt af Mennesket. Dersom nemlig Lilierne virkeligen havde saadanne Bekymringer, og den Talende var af den Mening, at den væsentligen samme Bekymring havde stort at betyde i Forhold til et Menneske: saa var det jo ikke Viisdom og Deeltagelse, men menneskelig Selvkjærlighed, der kunde tale saa kort, og saa afvisende om de stakkels Lilier, saa fornemt om Liliernes Smaa-Sorger, saa fornemt ved at kalde dem Smaa-Sorger, der ikke ere værd at agte paa. Sæt det nu var saa, at der var Forskjelligheder mellem Lilierne indbyrdes, som i deres lille Verden svarede $\mid$ til de menneskelige Forskjelligheder; sæt disse Forskjelligheder beskæftigede og bekymrede Lilierne, lige saa meget som Menneskene; - og sæt saa, at det i Sandhed var sandt, hvad der blev sagt: saadanne Forskjelligheder og saadanne Bekymringer ere ikke værd at agte paa.

Lader os nærmere betænke denne Sag; og da den Bekymrede, der gik ud til Lilierne paa Marken, jo netop ønskede at undgaae al Sammenligning med andre Mennesker, da han saa nødigt vilde, at noget andet Menneske skulde tale til ham om hans Bekymring: saa skal Talen ære hans Bekymring, jeg skal ikke tale om noget Menneske, eller om noget bekymret Menneske, men foretrække at tale om den bekymrede Lilie.

Der var engang en Lilie, den stod paa et afsides Sted ved et lille rindende Vand, og var godt kjendt af nogle Nelder samt et Par andre Smaablomster der i Nærheden. Lilien var, efter Evangeliets sandfærdige Beskrivelse, deiligere paaklædt end Salomo i al hans Herlighed, derhos sorgløs og glad saa lang Dagen var. Umærkeligt og livsaligt gled Tiden hen, som det rindende Vand, der nynner og svinder. Men da traf det sig, at der en Dag kom en lille Fugl og besøgte Lilien, den kom igjen den næste Dag, blev da borte i flere Dage, indtil den atter kom igjen, hvilket tyktes Lilien besynderligt og uforklarligt, uforklarligt, at Fuglen ikke blev paa samme Sted, ligesom Smaablomsterne, besynderligt, at Fuglen kunde være saa lunefuld. Men som det saa ofte gaaer, saa gik det ogsaa Lilien, at den netop derfor forelskede sig mere og mere i Fuglen, fordi den var lunefuld.

Denne lille Fugl var en slem Fugl; istedenfor at sætte sig i Liliens Sted, istedenfor at glæde sig ved dens Deilighed og glæde sig med den i dens uskyldige Lyksalighed, vilde Fuglen gjøre sig vigtig, ved at føle sin Frihed, og ved at lade Lilien føle dens Bundethed. Og ikke blot dette, men den lille Fugl var tillige snaksom, og fortalte nu Løst og Fast, Sandt og Usandt om, hvorledes der paa andre Steder, i stor Mængde, var ganske anderledes pragtfulde Lilier, hvor der var en Fryd og Munterhed, en Duft, en Farvepragt, en Fuglesang, som overgik al Beskrivelse. Saaledes fortalte Fuglen, og hver dens Fortælling endte gjerne med den for Lilien ydmygende Bemærkning, at den, i Sammenligning med saadan Herlighed, saae ud som Ingenting, ja at den var saa ubetydelig, at det var et Spørgsmaal, med hvad Ret den egentligen kaldtes Lilie.

Saa blev Lilien bekymret, jo mere den hørte paa Fuglen, jo mere blev den bekymret; den sov ikke mere roligt om Natten og vaagnede ikke mere glad om Morgenen; den følte sig fængslet og bunden, den fandt Vandets Rislen kjedsommelig og Dagen lang. Den begyndte nu at beskæftige sig med sig selv og med sit Livs Vilkaar i Selvbekymring - saa lang Dagen var. »Det kan jo være godt nok«, sagde den til sig selv, »engang imellem, for 
en Afvexlings Skyld, at høre paa Bækkens Rislen, men Dag ud og Dag ind evigt at høre det Samme: det er dog altfor kjedeligt.«»Det kan maaske være behageligt nok«, sagde den til sig selv, »engang imellem at være paa et afsides Sted og eensom, men saaledes, hele Livet igjennem, at være glemt, at være uden Selskab eller i Selskab med Brændenelder, hvad der dog vel ikke er Selskab for en Lilie: det er ikke til at udholde.«»Og saa at see saa ringe ud, som jeg gjør«, sagde Lilien til sig selv, »at være saa ubetydelig, som den lille Fugl siger jeg er: o, hvorfor er jeg dog ikke bleven til paa et andet Sted, under andre Vilkaar, o, hvorfor er jeg dog ikke bleven en Keiserkrone!« Thi dette havde den lille Fugl fortalt den, at Keiserkronen var blandt alle Lilier anseet for den skjønneste, og var Gjenstand for alle andre Liliers Misundelse. Lilien mærkede desto værre nok, at Bekymringen tog paa den; men saa talte den fornuftig til sig selv; dog ikke saaledes fornuftigt, at den slog Bekymringen af Sinde, men saaledes, at den overbeviste sig selv om, at Bekymringen var rigtig; »thi«, sagde den, »mit Ønske er jo ikke noget ufornuftigt Ønske, jeg forlanger jo ikke det Umulige, at blive hvad jeg ikke er, en Fugl f. Ex., mit Ønske er blot at blive en pragtfuld Lilie, eller vel endog den pragtfuldeste.«

Under alt Dette fløi den lille Fugl fra og til, med hvert dens Besøg og hver dens Adskillelse næredes Liliens Uro. Tilsidst fortroede den sig ganske til Fuglen. En Aftenstund aftalte de, at næste Morgen skulde der skee en Forandring, og gjøres en Ende paa Bekymringen. Næste Morgen tidlig kom den lille Fugl; med sit Næb huggede den Jordsmonnet bort fra Liliens Rod, at den saaledes kunde blive fri. Da dette var lykkedes, tog Fuglen Lilien under sin Vinge og fløi afsted. Bestemmelsen var nemlig den, at Fuglen skulde flyve med Lilien hen der, hvor de pragtfulde Lilier blomstrede; derpaa skulde Fuglen igjen være den behjælpelig $\mathrm{i}$ at blive plantet ned der, om det ikke ved Stedets Forandring og den nye Omgivelse skulde lykkes Lilien, at blive en pragtfuld Lilie i Selskab med de mange, eller maaskee endog en Keiserkrone, misundt af alle de andre.

$\mathrm{Ak}$, underveis visnede Lilien. Havde den bekymrede Lilie været nøiet med, at være Lilie, da var den ikke bleven bekymret; var den ikke bleven bekymret, saa var den bleven staaende hvor den stod - hvor den stod i al sin Deilighed; var den bleven staaende, da havde det netop været den Lilie, om hvilken Præsten talte i Søndags, da han gjentog Evangeliets Ord: »betragter Lilien, jeg siger Eder, at end ikke Salomo i al sin Herlighed var klædt som den.« Thi anderledes kan man dog vel ikke forstaae Evangeliet, hvorimod det er sørgeligt, ja næsten forfærdeligt, om det end er sandt, at en Fortolker af den hellige Skrift, ved det Sted om Lilierne, har fundet sig foranlediget til, i Lighed med den lille Fugl, at oplyse: at Keiserkronen voxer vild i hine Egne - som kunde man saa bedre forstaae, at Lilien i Deilighed overgaaer Salomo, som kunde man saa bedre forstaae Evangeliet, der altsaa ikke passede paa den uanseelige Lilie.

Saaledes gik det altsaa den bekymrede Lilie, hvis Bekymring var at blive en pragtfuld Lilie eller vel endog en Keiserkrone. Lilien er Mennesket. Den slemme lille Fugl er Sammenligningens urolige Tanke, der vanker vidt og bredt omkring, ustadigt og lunefuldt, og indsanker den usunde Viden om For skjelligheden; og ligesom Fuglen ikke satte sig i 
Liliens Sted, saa gjør Sammenligningen det Samme, ved den sætter Mennesket sig enten i en Andens Sted, eller en Anden i sit Sted. Den lille Fugl er Digteren, Forføreren, eller det Digteriske og Forføreriske i Mennesket. Det Digteriske er som Fuglens Tale, Sandt og Usandt, Digt og Sandhed; det er nemlig sandt, at Forskjelligheden er til, og at der er Meget at sige om den, men det Digteriske er, at Forskjelligheden lidenskabeligen, i Fortvivlelse eller Jubel, er det Høieste, og dette er evigt usandt. I Sammenligningens Bekymring gaaer da den Bekymrede tilsidst saa vidt, at han over Forskjelligheden glemmer, at han er Menneske, saa han fortvivlet mener sig at være saaledes forskjellig fra andre Mennesker, at han endog mener sig forskjellig fra det, at være Menneske, som jo ogsaa den lille Fugl meente, at Lilien var saa uanseelig, at det blev et Spørgsmaal, om den virkelig var Lilie. Men det formeentlig fornuftige Forsvar for Bekymringen er altid dette: at man jo ikke forlanger noget Ufornuftigt, at blive en Fugl f. Ex., men kun at blive dette Bestemte, man ikke er, selv om dette Bestemte igjen synes andre Bekymrede en reen Ubetydelighed. Naar saa Sammenligningen med Fuglens Bevægelse fra og til har hidset Bekymringens Lidenskab og faaet den Bekymrede revet løs fra Jordbunden, det er, fra at ville være hvad han er bestemt til: saa seer det et Øieblik ud, som kom nu Sammenligningen for at hente den Bekymrede til det ønskede Maal; men den kommer rigtignok og henter ham, dog kun som naar Døden henter et Menneske, den lader den Bekymrede omkomme i Mismodets Svæven.

Dersom nu Mennesket, ikke uden at smile, kan tænke paa Liliens Bekymring for at blive Keiserkrone, tænke paa, at den døde underveis: o, da betænke Mennesket, at det derimod er til at græde over, om et Menneske bekymredes lige saa ufornuftigt; lige saa ufornuftigt, dog nei, hvor turde jeg lade dette staae saaledes hen, hvor turde jeg saaledes for Alvor sigte de guddommeligt beskikkede Læremestere: Lilierne paa Marken. Nei, Lilien bekymres ikke saaledes, netop derfor skulle vi lære af den. Og naar da et Menneske, som Lilien, nøies med det, at være Menneske, saa bliver han ikke syg af timelig Bekymring; og naar han ikke bliver timeligt bekymret, saa bliver han staaende paa det Sted, ham er anviist; og naar han bliver der, da er det sandfærdigt saa, at han, ved at være Menneske, er herligere end Salomos Herlighed.

Hvad lærer altsaa den Bekymrede af Lilierne? Han lærer, at nøies med det at være Menneske, og ikke at bekymres om Forskjelligheden mellem Menneske og Menneske; han lærer, at tale lige saa kort, lige saa høitideligt, lige saa opløftende om det, at være Menneske, som Evangeliet taler kort om Lilierne. Og dette er jo dog ogsaa menneskelig Skik og Brug netop ved de høitideligste Leiligheder. Lad os tænke paa Salomo. Naar han da ifører sig det kongelige Purpur, naar han throner majestætisk i al sin Herlighed: nu ja, der lader sig ogsaa tale høitideligt saaledes, at den Talende siger: Deres Majestæt; men naar der, i Alvorens evige Sprog, skal tales allerhøitideligst, saa hedder det: Menneske! Og netop dette Samme sige vi til den Ringeste, naar han, liig Lazarus, ligger næsten ukjendelig i Armod og Elendighed, vi sige: Menneske! Og i det for et Menneskes Liv afgjørende Øieblik, naar Forskjellighedens Valg bydes, sige vi til ham: Menneske! Og i Dødens afgjørende Øieblik, naar alle Forskjelligheder afskaffes, sige vi: Menneske! Dog tale vi derfor ikke ringe, tvertimod vi sige det Høieste, fordi det, at være Menneske, ikke er lavere end Forskjellighederne, men 
er ophøiet over dem; thi denne den væsentligen lige Herlighed mellem alle Mennesker er dog vel ikke Dødens sørgelige Lighed, saa lidet som den væsentlige Lighed mellem alle Lilier, der jo netop er Lighed i Deilighed.

Al verdslig Bekymring har sin Grund i, at et Menneske ikke vil nøies med det at være Menneske, i, at hans ved Sammenligningen bekymrede Attraa er til Forskjelligheden. Den jordiske og timelige Bekymring derimod tør man ikke ligefrem og uden videre sige om, at den er Sammenligningens Opfindelse, thi at et Menneske, i Trangens virkelige Øieblik, behøver Føde og Klæder, det opdager han ikke ved Sammenligning; Den der levede eensomt blandt Lilierne paa Marken, vilde ogsaa opdage det. Næringssorgen, ak, eller som den jo almindeligere nævnes i et sørgeligt Fleertal, Næringssorgerne, ere ikke ligefrem Sammenligningens Opfindelse. Noget Andet er det, om dog ikke paa utallige Maader Sammenligningen tvetydigt arbeider med i Bestemmelsen af, hvad der skal forstaaes ved Næringssorg, om der dog ikke skulde være ... dog nei, den Bekymrede vil jo saa nødigt, netop for at undgaae Sammenligningen, at noget andet Menneske skal tale til ham desangaaende, nu vel, saa lad os sige saaledes: om man dog ikke af Fuglene skulde kunne lære Meget betræffende denne Sorg.

Dette ville vi nu betragte: hvorledes Den, bvem Naringssorgen volder Bekymring, ved ret at agte paa Himmelens Fugle larer, at noies med det at vare Menneske.

»Seer til Himmelens Fugle«. Seer til dem, det vil sige giv nøie Agt paa dem; saaledes kommer Fiskeren om Morgenen og seer til Snøren, som har ligget ude om Natten; saaledes kommer Lægen og seer til den Syge; saaledes staaer Barnet og seer til, naar den Ældre gjør Noget, som Barnet aldrig før har seet. Saaledes maa man, ikke med deelt Sind og adspredte Tanker, men med samlet Opmærksomhed og Eftertanke, om muligt med Forundring, nøie agte paa Fuglene. Vilde Nogen sige: en Fugl har man da seet saa tidt, det er dog vel ingen Mærkelighed: saa har han ikke forstaaet Indbydelsen i Evangeliet om Himmelens Fugle. - »Himmelens Fugle«, eller, som der siges et andet Sted, »Fuglene under Himmelen«. Vel seer man nemlig ogsaa Fuglene nede ved Jorden, seer dem paa Jorden, men dersom man ret skal have Gavn af at betragte dem maa man see dem under Himmelen, eller dog bestandigen i Forestillingen erindre, at de høre hjemme under Himmelen. Kunde Nogen, ved idelig at see en Fugl paa Jorden, glemme, at den var Himmelens Fugl, saa havde han forhindret sig selv $\mathrm{i}$ at forstaae Evangeliet om Himmelens Fugle. - »De saae ikke, og høste ikke, og sanke ikke i Lader.« Hvor skulde ogsaa Sligt kunne lade sig gjøre der, hvor Fuglene have Tilhold - under Himmelen, der, hvor de leve uden Timelighedens Forsynlighed, ukjendte med Tiden, i Øieblikket. Det forsynlige Menneske paa Jorden lærer af Tiden at benytte Tiden, og naar han fra en forbigangen Tid har Laden fuld, og er forsynet for den narvarende Tid, da passer han dog paa at saae igjen for en tilkommende Høst, at han atter kan have Laden fuld for en tilkommende Tid. Derfor bruges der tre Ord for at betegne Forsynlighedens Arbeiden; der siges ikke kort, som om Lilierne: de arbeide ikke; ved de tre Ord antydes Tidens Bestemmelse, hvilken ligger til Grund for Forsynligheden. - Og dog føder Eders himmelske Fader dem«. Den himmelske Fader, ja det er tydeligt, det maa være ham, dersom da Betragteren seer til Fuglene - under Himmelen; thi der, 
hvor Morgen, Middag og Aften, Bondemanden kommer ud, og kalder Fuglene sammen og giver dem Føde: der kan Betragteren let see feil, og troe, at det er Bondemanden, som føder Fuglene. Men der, hvor der ingen Bondemand er - paa Marken, der hvor der intet Forraadskammer er - under Himmelen, der, hvor de sorgløse Fugle uden at saae, uden at høste, uden at sanke i Lade - og uden Næringssorger svinge sig let over Skov og Søe: der maa det dog vel være den himmelske Fader, som føder dem. »Han føder dem«; eller skulle vi maaskee daarligen sige, hvad vel mangen daarlig Bondemand har sagt: »Fuglene stjæle«, saa det dog egentligen er Bondemanden, der føder Fuglene, fordi disse nemlig stjæle fra ham. Ak, dersom et Menneskes Tanke var sjunken saa dybt i ussel Elendighed, at han i fortredelig Alvor kunde mene noget Saadant: hvor skulde han vel kunne lære Opløftelse af Himmelens Fugle, hvor skulde det hjælpe ham, at see til Himmelens Fugle! Og dog, det skulde visseligen hjælpe ham, hvis han blot vilde see til dem, det vil sige, give nøie Agt paa dem, lære om igjen, lære at glemme den usle Forstandighed, der umenneskeligt gjorde hans Sjel smaalig. Nei, den himmelske Fader føder Fuglene, og det uagtet de ikke saae, og ikke høste og ikke sanke i Lader, det vil sige den himmelske Fader føder ogsaa de Skabninger, som saae og høste og samle i Lader, og derfor skal Den, som ernærer sig selv, af Himmelens Fugle lære, at det dog er den himmelske Fader, som føder ham. Men Den, der Intet, slet Intet eier paa Jorden; Den, der saaledes - ogsaa lever »under Himlen«; Den, der sørgeligt fornemmer, at han meget nær er i det - glade Slægtskab med Himmelens Fugle: han lærer, at den himmelske Fader føder dem.

»Seer til Himmelens Fugle - Eders himmelske Fader føder dem«. Hvor kort, hvor høitidelig, hvor ligelig er denne Tale. Der er talet om alle Fuglene, der er ikke glemt een eneste i Talen, som forklarer, at den himmelske Fader ei heller glemmer nogen eneste, han, som oplader sin milde Haand og mætter Alt hvad som lever med Velsignelse. I Evangeliets Tale om Fuglene ymtes der ikke det Mindste om nogen Forskjel; at den ene maaskee fik rigeligt, den anden knapt; den ene maaskee Forraad for lidt længere Tid, den anden kun det i Øieblikket Fornødne; at engang imellem den enkelte maatte vente, vente forgjeves, maatte maaskee gaae hungrig tilsengs: nei, der tales blot om Fuglene og om at den himmelske Fader føder dem.

Dog siger maaskee En: »om ogsaa en Fugl engang imellem fik for lidt, om der ogsaa døde en Fugl af Sult, den Sag var dog vel ikke saa farlig.« Hvorledes, skulde et Menneske kunne nænne at tale saaledes om Fuglene! Er og bliver da Bekymringen for Udkommet ikke væsentligen den samme enten det er en Fugl, der har den, eller et Menneske? Skulde et Menneske fornemt oversee denne Bekymring, dersom det blot var Fuglen, der kjendte den, og Mennesket var fritaget? Eller var det ufornuftigt af Fuglen at bekymres for saadanne Ubetydeligheder, men det var ikke ufornuftigt af det fornuftige Menneske at bekymres for de samme Ubetydeligheder? Sæt Fuglenes Liv ikke var ukjendt med den Forskjellighed i Henseende til Udkommet, hvilken desto værre gjøres saa gjeldende blandt Menneskene; sæt denne Forskjellighed beskæftigede og bekymrede Fuglene paa samme Maade, som den bekymrer Mennesket. 
Paa samme Maade - naar dette antages, saa kan Talen jo undgaae, hvad den Bekymrede saa nødigt vil, at et andet Menneske taler til ham om hans Bekymring, saa kan Talen blive ude paa Marken hos Fuglene og tale om Fuglens Bekymring.

Der var engang en Skovdue; i den skulende Skov, der hvor Forundringen boer med Gysen blandt de ranke eensomme Stammer, havde den sin Rede. Men næst ved, der hvor Røgen stiger op fra Bondemandens Huus, boede nogle af dens fjernere Slægtninge: nogle tamme Duer. Med et Par af disse traf den oftere sammen; den sad nemlig paa en Green, som bøiede sig ud over Bondens Gaard; de tvende tamme sad paa Rygningen af Taget, dog var Adskillelsen ikke større end at de kunde udvexle deres Tanker for hinanden i Samtale. En Dag talte de da sammen om Tidernes Leilighed og om Udkommet. Skovduen sagde: »jeg har hidtil saadan havt mit Udkomme, jeg lader hver Dag have sin Plage, og paa den Maade kommer jeg gjennem Verden.« Den tamme Due havde hørt nøie til ikke uden at fornemme en vis vellystig Bevægelse gjennem hele Legemet, hvilket kaldes at kroe sig, derpaa svarede den: »nei, da bære vi os anderledes ad; hos os, det vil sige hos den rige Bonde, hos hvem vi leve, har man sin Fremtid betrygget. Naar Høstens Tid kommer, saa sidder jeg eller min Mage, een af os sidder oppe paa Taget og passer paa. Saa kjører Bondemanden det ene Læs Sæd ind efter det andet, og naar han saa har kjørt saa mange ind, saa jeg ikke kan tælle længere, saa veed jeg, at der er Forraad nok for lang Tid, det veed jeg af Erfaring.« Da den havde talet saaledes, vendte den sig ikke uden en vis Selvfølelse om til dens Mage, der sad hos, som vilde den sige: »ikke sandt, min lille Mage, vi To har Vores sikkret.«

Da Skovduen kom hjem, tænkte den nærmere over denne Sag; det forekom den strax, at det maatte være en stor Behagelighed saaledes at vide, at man havde sit Udkomme betrygget for lang Tid, hvorimod det dog var kummerligt saaledes bestandigt at leve paa det Uvisse, saa man aldrig tør sige, at man veed man er forsørget. Det bliver derfor bedst, tænkte den, at Du forsøger, om det ikke skulde lykkes Dig at samle et større Forraad ind, som Du kunde have liggende paa eet eller andet meget sikkert Sted.

Næste Morgen vaagnede den tidligere end sædvanligt og havde nu saa travlt for at sanke sammen, at den neppe fik Tid til at spise eller til at spise sig mæt. Men det var ligesom en Skjæbne, der var over den, at den ikke skulde faae Lov at samle Velstand, thi hver Gang den havde samlet en Smule Forraad og gjemt det paa eet eller andet af de formeentligen sikkre Steder - naar den kom for at see efter, saa var det borte. Imidlertid foregik der ingen væsentlig Forandring i Henseende til Udkommet, den fandt hver Dag sin Føde ligesom før, og forsaavidt den tog lidt knappere til sig, da var det fordi den vilde samle og fordi den ikke gav sig Tid til at spise, thi ellers havde den sit rigelige Udkomme som før. Ak, og dog var der foregaaet en stor Forandring med den, den leed langtfra virkelig Trang, men den havde faaet en Forestilling om Trang i Fremtiden, dens Ro var tabt - den havde faaet Naringssorg.

Fra nu af blev Skovduen bekymret, dens Fjær tabte Farvespillet, dens Flugt Letheden; dens Dag gik hen i frugtesløse Forsøg paa at samle Velstand, dens Drømme vare 
Indbildningens afmægtige Planer; den var ikke mere glad, ja den var næsten som bleven misundelig paa de rige Duer; den fandt sin Føde hver Dag, blev mæt, og dog var det ligesom blev den ikke mæt, fordi den i Næringssorgen hungrede for lang Tid; den havde fanget sig selv i den Snare, hvori ingen Fuglefænger kunde fange den, hvori kun den Fri kan fange sig selv: i Forestillingen. »Vel sandt«, sagde den til sig selv, »vel sandt, naar jeg hver Dag faaer saa meget jeg kan spise, saa har jeg jo mit Udkomme; det store Forraad jeg ønsker at samle kunde jeg dog ikke spise paa eengang, og i en vis Forstand kan man da ikke mere end spise sig mæt; men det var dog en stor Behagelighed at være fritaget for denne Uvished, hvorved man bliver saa afhængig.«»Det kan nok være«, sagde den til sig selv, »at de tamme Duer dyrt kjøbe deres visse Udkomme; det kan nok være, at de i Grunden har mange Bekymringer, som jeg hidtil har været fritagen for, men denne Fremtidens Betryggethed staaer mig bestandigt for Hovedet; o, hvorfor blev jeg dog en fattig Skovdue og ikke en af de rige Duer!« Saa mærkede den nok, at Sorgen tog paa den, men da talte den fornuftigt til sig selv, dog ikke saaledes fornuftigt, at den slog Bekymringen af Tanke, og Sindet til Ro, men saaledes, at den overbeviste sig selv om, at Sorgen var i sin Orden. »eg forlanger jo ikke noget Ufornuftigt«, sagde den, »eller noget Umueligt, jeg forlanger jo ikke at blive som den rige Bonde, men blot som een af de rige Duer.«

Tilsidst udtænkte den en List. En Dag fløi den hen og satte sig paa Rygningen af Bondemandens Tag mellem de tamme Duer. Da den derpaa lagde Mærke til, at der var et Sted, hvor disse fløi ind, fløi den ogsaa derind, thi der maatte vel Forraadskamret være. Men da Bondemanden kom om Aftenen og lukkede Dueslaget, opdagede han strax den fremmede Due. Denne blev derpaa sat ind i et lille Aflukke for sig selv indtil den næste Dag, da den blev aflivet - og fritagen for Næringssorgen. Ak, den bekymrede Skovdue havde ikke blot fanget sig selv i Bekymringen, men ogsaa paa Dueslaget fanget sig selv - til Døden.

Havde Skovduen været nøiet med at være hvad den var: Himmelens Fugl, da havde den havt sit Udkomme, da havde den himmelske Fader født den, da var den, paa Uvishedens Vilkaar, blevet hvor den hørte hjemme, der hvor de ranke, eensomme Stammer tungsindigt ere i god Forstaaelse med Skovduens kurrende Trille; da havde det været Den, om hvilken Præsten talte i Søndags, da han gjentog Evangeliets Ord: seer til Himmelens Fugl, den saaer ikke og høster ikke og sanker ikke i Lade, dog føder Eders himmelske Fader den.

Skovduen er Mennesket - dog nei, lader os ikke glemme, at det kun er Talen, der af Ærbødighed for den Bekymrede har ladet Skovduen holde for. Ja, som naar et fyrsteligt Barn opdrages, der da er et fattigt Barn, hvilket bliver straffet $\mid$ istedenfor Fyrsten: saaledes har Talen ladet Alt gaae ud over Skovduen. Og den har villigen fundet sig deri, thi den veed meget godt, at den er een af de guddommeligt beskikkede Lærere, af hvilke vi skulle lære; men dette gjør en Lærer ogsaa stundom, at han paa sig selv viser det Forkeerte, han vil advare imod. Skovduen selv er sorgløs, ja det er virkelig den, om hvilken Evangeliet taler. - Altsaa Skovduen er Mennesket. Naar han, som den, nøies med at være Menneske, da forstaaer han, hvad han lærer af Himmelens Fugl, at den himmelske Fader føder ham. Men føder den himmelske Fader ham, da er han jo uden Næringssorg, da boer han ikke 
blot som de tamme Duer hos den rige Bonde, men han boer hos Den, som er rigere end Alle. Han boer virkeligen hos ham, thi da Himmel og Jord er Guds Huus og Eiendom, saa boer Mennesket jo hos ham.

Dette er det: at nøies med at være Menneske, at nøies med at være den Ringe, Skabningen, der ligesaalidet kan opholde sig selv, som skabe sig selv. Vil Mennesket derimod glemme Gud - og ernære sig selv; saa har vi Næringssorgen. Det er vistnok priseligt og Gud velbehageligt, at et Menneske saaer og høster og sanker i Lade, at han arbeider for at finde Føden; men vil han glemme Gud og mene ved sin Arbeiden at ernære sig selv, saa har han Næringssorg. Den rigeste Mand, der nogensinde har levet, hvis han glemmer Gud og mener at ernære sig selv; han har Næringssorg. Thi lader os ikke tale daarligen og smaaligt, ved at sige, at den Rige er fritagen for Næringssorg, den Fattige ikke. Nei, kun Den er fritagen, som ved at nøies med det at være Menneske, forstaaer, at den himmelske Fader føder ham; og dette kan jo den Fattige lige saa godt som den Rige.

Næringssorg er derfor den Snare, hvori ingen udvortes Magt, ingen Virkelighed kan fange et Menneske, men hvori kun han kan fange sig selv, den Rige lige saa godt som den Fattige - naar han ikke vil nøies med det at være Menneske. Naar han nemlig ikke vil nøies dermed, hvad er da det Mere han forlanger? Det Mere er: at være sig selv sit $\mid$ eget Forsyn for hele Livet eller maaskee blot for den Dag imorgen; og naar han vil det, saa gaaer han - snildt - i Snaren, den Rige lige saa godt som den Fattige. Saa vil han ligesom omskandse sig selv paa en lille eller en stor Plet, der ikke skal være Gjenstand for Guds Forsyns og den himmelske Faders forsørgende Omsorg. Han mærker maaskee ikke, førend det er forsilde, at han i denne omskandsede Tryghed boer - i et Fængsel. Han gjør selv, hvad Bondemanden gjorde ved Duen, han lukker Slaget, og troer, at han nu er tryg, og nu er han netop fangen, eller, hvilket ogsaa kan udtrykkes paa en anden Maade, nu er han netop udelukket fra Forsynets Omsorg og priisgiven til Næringssorg. Thi kun Den er fangen og udelukket, som har lukket sig inde hos meget eller lidet Gods i den Mening at ernære sig selv; og kun Den er fri og uden Næringssorg, som hos meget eller lidet Gods, ja i Armod forstaaer, at den himmelske Fader føder ham. Og Den, der i formastelig Forstand snildt har lukket sig selv inde og derved fanget sig selv, han har netop, som Skovduen, aandeligt forstaaet, fanget sig selv til Døden.

Allerede saaledes viser det sig, at Næringssorg fremkommer ved Sammenligning; her nemlig paa den forfærdelige Maade, at Mennesket ikke vil nøies med at være Menneske, men vil sammenligne sig med Gud, vil have en Tryghed ved sig selv, som intet Menneske tør have, hvilken Tryghed derfor ogsaa netop er - Næringssorgen.

Men ogsaa paa andre Maader viser det sig, at Næringssorg fremkommer ved Sammenligning, forsaavidt nemlig Næringssorg ikke er den Dag idags virkelige Trang, men Forestillingen om en fremtidig. Sammenligningen fremkommer da atter ved, at Mennesket ikke vil nøies med det at være Menneske. Himmelens fattige Fugl sammenlignede sig jo med de rige Fugle; ved denne Sammenligning opdagede den Næringssorgen. Hvad det er at hungre og at finde Føde, det havde den vidst for længe siden, men Næringssorg havde 
den ikke før havt. Og da nu disse Bestemmelser: riig og fattig, ikke ved et svælgende Dyb ere skilte fra hinanden, da de tvertimod i idelig Omgang og stadig Grændsestrid berøre hinanden, og da fremdeles det forskjellige Hensyn forholdsviis forandrer Bestemmelsen: saa kan altsaa dette Sammenligningens Tredie være det yderst Forskjellige. I Næringssorgen vil saa den Bekymrede ikke nøies med det at være Menneske, men vil være eller have Forskjelligheden, vil være riig, formuende, velhavende, nogenlunde betrygget og saa fremdeles. Han seer nemlig ikke til Himmelens Fugle - bort fra Menneskelivets Forskjellighed, men han seer sammenlignende til de Andre, til Forskjelligheden, og hans Næringssorg er et Sammenligningens Forhold.

Og selv om den Bekymrede ikke saaledes i Sammenligning fæster sin Opmærksomhed paa Grads-Forskjellen, og kalder Det Næringssorg, som mere er verdslig Bekymring (thi det er jo dog ikke Næringssorg, at bekymres om at have lige saa meget som Den og Den), selv om dette ikke er Tilfældet, der ligger dog en Sammenligning til Grund for Næringssorgen, forsaavidt denne ikke er Udtrykket for den virkelige men den forestillede Trang. Hvoraf kommer det, at Fuglen ikke har Næringssorg? Deraf, at den ikke sammenligner den ene Dag med den anden, at den efter Evangeliets Ord lader hver Dag have sin Plage. Men selv om den Bekymrede ikke sammenligner sit Kaar med noget andet Menneskes, og i denne Forstand »holder sig reen fra Verden« (ak, Sammenligning er maaskee en af de fordærveligste Arter Besmittelse) - naar han dog ængstelig sammenligner den ene Dag med den anden, naar han den Dag han har rigeligt Udkomme siger: men imorgen! og naar han den Dag han har knapt siger: imorgen vil det blive endnu værre: saa sammenligner han jo. Ak, hvis en saadan Bekymret læste dette, at han da ikke vilde blive utaalmodig paa Taleren. Gjerne skal jeg som en hedensk Viis gjorde af Ærbødighed for Talens Gjenstand: tildækkede sit Aasyn, gjerne skal jeg saaledes af Ærbødighed for Bekymringen tildække mit Ansigt, saa jeg Ingen seer, men kun taler om Himmelens Fugl. Det var jo ved denne Art af Sammenligning, at Skovduen i Bekymringens sørgelige Omgang med sig selv fra Dag til Dag opdagede Næringssorgen; den tilstod jo, at den havde sit Udkomme, men Uvisheden bedrøvede den, den syntes den blev saa afhængig - af Gud. Det græmmede den, at den aldrig med Sikkerhed turde tale om den næste Dag - o, lad os dog ikke glemme, at den jo i guddommelig Forstand turde tale med Sikkerhed, naar den sagde: den himmelske Fader vil nok føde mig imorgen; lad os ikke glemme, at den talede med allerstørst Sikkerhed om den Dag imorgen, hvis den ret inderligt indskrænkede sig til blot at takke for den Dag idag! Er dette ikke saaledes? Dersom der var en elskende Pige, hvem den Elskede kom og besøgte, hvis hun da sagde til ham: kommer Du nu ogsaa igjen imorgen: da var der dog jo nogen Bekymring i hendes Elskov. Men hvis hun uden at nævne den Dag imorgen kastede sig om hans Hals og sagde: o, tak, at Du kom idag: da var hun jo ganske beroliget for den Dag imorgen. Eller, hvis der var tvende Piger, og den ene sagde til sin Elskede: kommer Du nu ogsaa imorgen igjen; den anden sagde: o, tak at Du kom idag: hvilken af disse Tvende var meest overbeviist om, at den Elskede vilde komme imorgen igjen? 
Der føres ofte nok i Verden den unyttige og maaskee forfængelige Strid, naar den Fattige siger til den Rige: ja, Du kan sagtens, Du er fri for Næringssorg. Give Gud, at den Fattige dog ret vilde forstaae, hvorledes Evangeliet mener det saa langt bedre med ham, ligeligt og mere kjærligt. Evangeliet lader sig sandeligen ikke bedaare af den synlige Forskjelligheds Sandsebedrag, lader sig ikke bedaare til at tage Partie med noget Menneske mod noget andet Menneske, med den Rige mod den Fattige eller med den Fattige mod den Rige. Det, ikke at have Næringssorg, er i Sandhed en Velbehagelighed i Guds Øine: skulde da vel den Rige uden videre have dette Fortrin, og den Fattige være udelukket? Ak, nei. Hvis den Fattige ret vilde nøies med det at være Menneske, og af Himmelens Fugle lære at være uden Næringssorg, da skulde han eenfoldigen opløfte sig over den tilsyneladende Forskjellighed, han skulde maaskee stundom foranlediges til at sige: den stakkels Rige, han har dog ret Næringssorg. Thi hvilket Menneske kan dog vel med Rette og med Sandhed sige disse Ord: jeg | har ingen Næringssorg? Dersom den Rige, idet han siger det, peger paa sine Rigdomme: mon der da er Spoer af Mening i hans Tale! Modsiger han sig ikke i samme Øieblik himmelraabende, han, som holder Næringssorgen fast, idet han holder den borte ved sine Skatte, og af Næringssorg passer nøie paa dem og forøger dem! Ja, dersom den Rige vilde bortgive alt sit Gods, kaste Pengene - og Næringssorgerne fra sig og nu sige: jeg har ingen Næringssorg: da først var der jo Mening i hans Tale. Og dette er jo den Fattiges Tilfælde, naar han, som Intet eier og forsaavidt Intet har at bortkaste, kaster Næringssorgen paa Gud og siger: jeg har ingen Næringssorg. Er dette ikke saaledes, at Rigdommene maae bort, dersom det blot skal være muligt, at der kan være Mening i Talen? Dersom En, der eiede en kostbar Samling af herlige Lægemidler, af hvilke han daglig brugte Noget, vilde, idet han pegede paa Lægemidlerne, sige: jeg er ikke syg - var dette da ikke en himmelraabende Modsigelse!

Ofte nok føres der i Verden mellem Menneske og Menneske den unøisomme Sammenligningens Strid om Afhængighed og Uafhængighed, om det Lykkelige i at være uafhængig og det Tunge i at være afhængig. Og dog, dog har det menneskelige Sprog aldrig, og Tanken aldrig udfundet et skjønnere Sindbillede paa Uafhængighed end Himmelens - fattige Fugl; og dog, dog kan ingen Tale være mere besynderlig end at det skulde være saa Tungt at være - let som Fuglen! At være afhængig af sine Skatte, det er Afhængighed og tung Trældom; at være afhængig af Gud, ganske afhængig, det er Uafhængighed. Den bekymrede Skovdue frygtede daarligen at blive ganske afhængig af Gud, derfor ophørte den at være uafhængig og at være Sindbilledet paa Uafhængighed, ophørte at være Himmelens fattige Fugl, der ganske er afhængig af Gud. Afhængighed af Gud er den eneste Uafhængighed, thi Gud har ingen Tyngde, det har kun det Jordiske og især jordiske Skatte, Den, der derfor er ganske afhængig af ham, han er let. Saaledes med den Fattige, naar han, nøiet med det at være Menneske, seer til Fuglen under Himmelen, seer til den - under Himmelen, som jo altid den Bedende seer op ad, den Bedende, nei han, den Uafhængige, er jo en Takkende. 
At noies med det at vare Menneske. Det var derom Talen handlede, og om hvorledes den Bekymrede lærer det af Lilierne paa Marken og af Himmelens Fugle, hvorledes derimod Sammenligningen avlede den verdslige Bekymring, og hvorledes den avlede Næringssorgen. Det er vel et Menneske, der har talet, men han har jo, understøttet af Lilierne og Fuglene, talet om Lilierne og Fuglene. Og saaledes indeholder det, at han er den Talende, ingen Sammenligning med noget andet Menneske, som havde han noget Fortrin ved at være Taler; nei, her er atter Ligeligheden ligeoverfor de guddommeligt beskikkede Lærere: Lilierne paa Marken og Himmelens Fugle. 


\title{
O que aprendemos dos lírios do campo e das aves do céu
}

\author{
Soren Kierkegaard
}

Tradução do dinamarquês:

Alvaro L. M. Valls

\section{Este santo evangelho é escrito pelo evangelista Mateus (cap. 6 , vers. 24 até o final).}

Este santo evangelho é escrito pelo evangelista Mateus (cap. 6, vers. 24 até o final).

Ninguém pode servir a dois senhores. Com efeito, ou odiará um e amará o outro, ou se apegará ao primeiro e desprezará o segundo. Não podeis servir a Deus e ao Dinheiro. 25. Por isso vos digo: não vos preocupeis com a vossa vida quanto ao que haveis de comer, nem com o vosso corpo quanto ao que haveis de vestir. Não é a vida mais do que o alimento e o corpo mais do que a roupa? 26. Olhai as aves do céu: não semeiam, nem colhem, nem ajuntam em celeiros. E, no entanto, vosso Pai celeste as alimenta. Ora, não valeis vós mais do que elas? 27. Quem dentre vós, com as suas preocupações, pode acrescentar um só côvado à duração da sua vida? 28. E com a roupa, por que andais preocupados? Aprendei dos lírios do campo, como crescem, e não trabalham e nem fiam. 29. E, no entanto, eu vos asseguro que nem Salomão, em toda sua glória, se vestiu como um deles. 30. Ora, se Deus veste assim a erva do campo, que existe hoje e amanhã será lançada ao forno, não fará ele muito mais por vós, homens fracos na fé? 31. Por isso, não andeis preocupados, dizendo: Que iremos comer? Ou, que iremos beber? Ou, que iremos vestir? 32. De fato, são os gentios que estão à procura de tudo isso: o vosso Pai celeste sabe que tendes necessidade de todas essas coisas. 33. Buscai, em primeiro lugar, o Reino de Deus e a sua justiça, e todas essas coisas vos serão acrescentadas. 34. Não vos preocupeis, portanto, com o dia de amanhã, pois o dia de amanhã se preocupará consigo mesmo. A cada dia basta o seu mal.

Quem não conheceu este santo evangelho desde a sua mais tenra infância, e não se alegrou muitas vezes com esta boa-nova²! E contudo esta não é uma boa nova pura e simplesmente; ela tem uma propriedade essencial que bem propriamente faz dela um

2 glade Budskab: lit. alegre notícia. 
evangelho, ou seja, que se dirige ao que está preocupado ${ }^{3}$; sim, em cada linha do evangelho preocupado é fácil reconhecer que o discurso não é para os sadios, para os fortes, não é para os afortunados, porém para os preocupados; ó, é muito perceptível que a boa-nova faz, ela mesma, o que ela diz que Deus faz, acolhendo para si os aflitos e assumindo o cuidado deles - da maneira correta. Ai, isto decerto se faz necessário, pois todo aquele que tem pesar, e em especial quanto mais profunda e longamente este penetra na alma, ou quanto mais longamente penetra a fundo nela, talvez também sirva de tentação para impacientemente recusar-se a ouvir o discurso humano sobre consolo e esperança. Quiçá o pesaroso não tenha razão, talvez seja demasiado impaciente, quando lhe parece ser assim, que nenhum homem possa lhe falar de modo adequado ao seu pesar; pois o afortunado não o compreende; o forte parece elevar-se acima dele, ao consolá-lo; o [outro] preocupado apenas aumenta-lhe o pesar com a sua contribuição. Quando as coisas estão assim, é melhor portanto procurar para si outros mestres, cujo discurso não seja um mal-entendido, cujo encorajamento não contenha nenhuma censura oculta, cujo olhar não julgue ou condene, cujo consolo não inflame ao invés de acalmar.

Para tais mestres o evangelho preocupado orienta o pesaroso: aos lírios do campo e às aves do céu. Junto a estes modestos mestres, a quem a gente nem paga com dinheiro nem com humilhações, não há mal-entendido possível, pois eles se calam - por cuidado para com o aflito. E todo mal-entendido surge sempre com o discurso, compreendido mais de perto, que o discurso, especialmente o diálogo, contém uma comparação, que quando o afortunado diz ao aflito: sê alegre, aí a sentença inclui ao mesmo tempo: como eu sou; e quando o forte diz: sê forte, aí se subentende: como eu sou. Mas o silêncio honra a aflição e honra o aflito, como os amigos de Jó, que por reverência sentavam-se calados junto ao sofredor e o apoiavam honrosamente 4 . E no entanto, olhavam, afinal, para ele! Mas isto, que um homem olhe para o outro, contém outra vez uma comparação. Os silenciosos amigos não comparavam Jó com eles mesmos, isto só aconteceu quando romperam a honra (em que calados o apoiavam) e o silêncio, para com discursos se abaterem sobre o sofredor; mas suas presenças provocaram Jó a se comparar consigo mesmo. Com efeito, desta maneira nenhum homem pode estar presente, mesmo que se cale, que sua presença comparativamente não signifique absolutamente nada. No máximo, pode fazê-lo uma criança, que aliás tem também alguma semelhança com os lírios do campo e com as aves do céu; quantas vezes um sofredor não reconheceu e percebeu comovido que quando somente uma criança está presente, não há propriamente ninguém presente. E agora então, o lírio do campo! Por mais abundante que seja o seu sustento, ele não compara seu bem-estar com a pobreza de alguém; por mais despreocupado que esteja em sua formosura, ele não se compara nem com Salomão nem com o mais miserável de todos. E por mais que a ave saia voejando ligeiro pelas nuvens, ela não compara seu voo tão leve com o caminhar tão

3 Bekymrede: aflito ou preocupado.

4 Jó 2, 13. 
pesado do aflito; se o pássaro, mais rico do que aquele que tem cheios os seus celeiros, não recolhe no celeiro: ele não compara sua rica independência com o que sofre sob a necessidade, que junta em vão. Não, lá onde o lírio floresce formosamente - no campo, lá onde o pássaro está livremente em casa - sob o céu, caso se procure consolo: lá há um silêncio ininterrupto, lá não há ninguém presente, lá tudo é apenas persuasão.

Todavia, as coisas só são assim se o preocupado realmente atenta aos lírios e às aves, pensando neles e em suas vidas esquece de si mesmo, enquanto neste esquecimento de si aprende deles, por si mesmo, imperceptivelmente algo sobre si mesmo; imperceptivelmente, pois ali só há silêncio, não há ninguém presente, o aflito está livre de todo e qualquer saber compartilhado, exceto o de Deus, o seu próprio - e o dos lírios.

Vamos então refletir neste discurso, de que modo o preocupado, ao olhar bem para os lírios do campo e para as aves do céu, aprende a:

\section{contentar-se em ser homem.}

"Observai os lírios do campo", observa-os, isto quer dizer presta atenção a eles, torna-os objetos, não de uma olhada fugaz de passagem, mas de tua observação; por isso esta expressão é utilizada ali, como o pastor costuma empregá-la no mais sério e solene dos contextos, quando diz: Vamos, nesta hora de devoção, observar isto e aquilo ${ }^{5}$. Tão solene é a exigência e o convite; muitos vivem talvez na cidade grande e nunca veem os lírios; muitos vivem talvez na campanha e passam por eles diariamente indiferentes; ai, quantos há, quiçá, que os observam bem, conforme a recomendação do Evangelho! - "Os lírios do campo", pois não se trata das plantas raras que um jardineiro amorosamente cultiva em seu jardim, e que são observadas pelos expertos; não, vai até o campo, lá onde ninguém se desvela pelos lírios abandonados, e onde fica tão patente que eles não estão abandonados. Como é que esta exigência não seria convidativa para o preocupado, ai, afinal também ele, como o lírio abandonado, está abandonado, desconhecido, negligenciado, sem o cuidado humano, até que, ao observar bem o lírio, compreenda que não está abandonado.

O aflito vai então ao campo, e para junto dos lírios. Não como o faz decerto a criança feliz, nem como um adulto senil, que corre por aí para encontrar o mais bonito, para satisfazer a curiosidade ao encontrar o mais raro. Não, com tranquila solenidade observa-os, vê como eles ficam parados lá, em multidão numerosa, colorida, um tão bem quanto o outro - "como eles crescem". Ora, como eles crescem, ele propriamente não vê, pois afinal é como diz o provérbio, a gente não pode ver a grama crescer, e não obstante, ele vê de que modo crescem, ou justamente porque o modo como eles crescem lhe é inconcebível, ele vê que tem de haver alguém que os conheça com tanta exatidão como o jardineiro conhece as plantas raras; alguém que diariamente se ocupe deles, de manhã e de noite, tal como o jardineiro se ocupa das plantas raras; alguém que lhes proporcione incremento.

5 Referência a expressões que o Bispo Mynster utilizava em sua pregação dominical. (N.T.) 
É provável que seja também o mesmo alguém que proporciona incremento às plantas raras do jardineiro, só que essas tão facilmente provocam um mal-entendido por causa do jardineiro. Os lírios abandonados, por outro lado, os lírios comuns, lírios do campo, não ocasionam ao observador nenhum mal-entendido. Pois lá onde o jardineiro é visível, lá onde não se poupam esforços nem custos para cultivar plantas raras para o homem rico, parece que talvez dê para compreender melhor que elas cresçam; mas ao contrário, no campo, onde ninguém, ninguém, ninguém se preocupa com os lírios, de que modo eles podem lá crescer? E no entanto eles crescem.

Mas então os pobres lírios decerto têm de trabalhar eles mesmos com tanto mais rigor. Não, "eles não trabalham"; são somente as flores raras as que estão ligadas a tanto trabalho, para que possam chegar a crescer. Lá onde o tapete é mais precioso que o dos salões dos reis, lá não se trabalha. Enquanto o olhar do observador se diverte e se refrigera com a visão, sua alma não deve se preocupar com o pensamento sobre de que modo os pobres coitados dos lírios têm de trabalhar e labutar para conseguir tapete tão bonito. Só em relação ao produto da habilidade artística humana as coisas são assim, que o olhar, enquanto se deslumbra pelo esplendor do trabalho, enche-se de lágrimas com o pensamento nos sofrimentos da coitada da mulher rendeira.

Os lírios "não trabalham, não fiam", não se encarregam propriamente de outra coisa senão de se enfeitar, ou ainda melhor: de estar enfeitados. Tal como na passagem anterior do Evangelho, onde se fala dos pássaros, quando se diz: "eles não semeiam, não colhem nem juntam nos celeiros", assim também se refere ao trabalho do homem para sustentar a si e aos seus: assim contém essas palavras sobre os lírios (eles não trabalham, não fiam) também uma alusão ao trabalho da mulher. A mulher fica em casa, não sai para a rua a fim de buscar as coisas necessárias para a vida, ela permanece no lar, costura e fia, busca manter tudo tão enfeitado quanto possível; sua ocupação cotidiana, seu trabalho aplicado está mais próximo do esmero ${ }^{6}$. Assim também o lírio: ele fica em casa, não sai de seu lugar, mas não trabalha, não fia - só se enfeita, ou melhor ainda, está enfeitado. Se o lírio devesse ter alguma preocupação, então não seria com o sustento, como porém poderia parecer que o pássaro a tem, já que este voa numa área tão vasta e tão larga e recolhe alimento, não, a preocupação do lírio poderia estar à maneira feminina em relação com o estar ou não estar enfeitado também agora. Mas ele está sem preocupação.

Pois enfeitado ele está, com certeza; sim, o observador não pode deixar ficar, ele se curva para um lírio qualquer, ele toma o primeiro que alcança - "eu vos asseguro que nem Salomão, em toda sua glória, se vestiu como um deles". Observa-o então minuciosamente e de perto, e ainda que o seu espírito estivesse inquieto, ai, tal como um espírito humano pode estar inquieto, e ainda que seu coração batesse impetuosamente, ai, tal como um coração humano pode fazê-lo, ele se entrega inteiramente à tranquilidade, tão somente para observar este lírio. Quanto mais exatamente olha, mais se surpreende com sua formosura e sua

6 Pyntelighed: atilamento, aperfeiçoamento, capricho. 
engenhosa formação; pois só em relação com o produto da habilidade artística humana vige que quanto mais minuciosamente se olha, mais falhas e imperfeições se descobrem, e vige, que se aguças o teu olhar com a lente esmerilhada artisticamente, aí tu mesmo enxergas no interior do mais fino tecido as malhas rudes. Ai, é como se o homem para sua própria humilhação fizesse a descoberta naquilo de que se orgulhava; quando aprendeu a polir artificialmente o vidro, de modo a aumentar o objeto, então ele descobriu, com a ajuda da lente de aumento, que mesmo o mais perfeito dos trabalhos humanos é rude e imperfeito. Mas a descoberta, que humilhava o ser humano, reverenciava a Deus, pois jamais alguém descobriu, com a ajuda da lupa, que o lírio ficava menos formoso, menos engenhoso, pelo contrário, mostrou ser ainda mais e mais formoso, mais e mais engenhoso. Sim, a descoberta honrava a Deus, como toda e qualquer descoberta deve fazê-lo, pois só em relação a um artista humano vale que aquele que o conhece com mais exatidão, mais de perto e no uso diário, vê, afinal, que ele não é tão grande; em relação com o artista que fia o tapete do campo e causa ${ }^{7}$ a formosura do lírio, vale que a surpresa aumenta com a proximidade, que a distância da adoração cresce com a aproximação a ele.

Assim, o aflito que foi até os lírios com sua tristeza paira entre eles, no campo, surpreso pela formosura do lírio que observa; ele apanhou o primeiro que viu, não fez nenhuma escolha, simplesmente nem lhe ocorre que devesse haver algum único lírio, tampouco como uma palha no campo, a respeito da qual não valesse que nem mesmo Salomão em toda a sua glória jamais se vestiu como um deles. Suposto que o lírio pudesse falar, aí ele não diria para o aflito: "por que te surpreendes desta maneira a meu respeito? Acaso o [fato de] ser homem não seria igualmente glorioso, não valeria a este respeito que mesmo Salomão em toda a sua glória nada é em comparação com aquilo que cada ser humano é, por ser homem, de modo que Salomão, para ser o mais glorioso de todos, como é, e ter consciência disto, teria de despojar-se de todo o seu esplendor e ser meramente um ser humano? Acaso o que vale para mim, pobre coitado, não haveria de valer para o ser um homem, que é, afinal de contas, o prodígio da criação?”. Contudo, o lírio não pode falar, mas justamente porque não pode falar, justo porque lá fora tudo é silêncio e não há ninguém presente, por isso justamente é o aflito, se ele fala e se fala com o lírio, neste caso é ele que fala consigo mesmo; sim, aos poucos ele descobre que fala sobre si mesmo, que aquilo que diz sobre o lírio ele diz sobre si mesmo. Não é o lírio que o diz, ele não sabe falar; nem é algum outro homem que o diz para ele; pois com o outro homem chega-se afinal muito depressa e facilmente ao pensamento inquieto da comparação; entre os lírios, o preocupado é só um ser humano e - satisfeito com ser um homem. Pois bem, no mesmo sentido em que o lírio é lírio, inteiramente no mesmo sentido ele é ser humano, apesar de todas as suas preocupações como ser humano; e inteiramente no mesmo sentido, como o lírio, sem trabalhar e sem fiar, é mais belo do que a glória de Salomão, bem no mesmo sentido é também o ser humano, sem trabalhar, sem fiar, sem nada de meritório de sua parte, ao

7 virker: atua, opera, produz o efeito. 
ser um humano é mais glorioso do que a glória de Salomão. Não está dito no Evangelho, de jeito nenhum, que o lírio é mais glorioso do que Salomão, não, ali está escrito que ele está mais bem vestido do que Salomão em toda a sua glória. Ah, mas no trato contínuo com os humanos, na variada diversidade, e em seus diversos contatos, esquece-se, com a frenética ou preocupada inventividade da comparação, o que significa ser um humano, a gente esquece devido à diversidade entre um homem e outro. Mas no campo, junto aos lírios, onde o céu se arqueia lá no alto - como sobre um dominador, livremente - como a respiração está lá fora, onde os grandes pensamentos das nuvens dispersam tudo o que é acanhado: lá o preocupado é o único ser humano, que aprende dos lírios o que ele talvez não poderia aprender de um outro ser humano.

“Observai os lírios no campo.” Quão breve, quão solene, quão equiparador é este discurso sobre os lírios; não há vestígios de ideia, não se murmura nem o mínimo sobre a possibilidade de haver alguma diferença entre um lírio e outro; trata-se de todos eles e de cada um enquanto único; trata-se de todos de maneira igual: os lírios. Quiçá alguém vá achar que é estranho, porém, e seja exigir demais que a linguagem humana deva imiscuir-se nas diferenças dos lírios entre si e suas possíveis preocupações, ocasionadas pela diferença; quiçá alguém venha a achar: "Tais diferenças e tais preocupações não são dignas de atenção". Vamos ver se nos entendemos. O que se quer dizer é que ou para os lírios não vale a pena prestar atenção a tais preocupações, isto é, que os lírios deveriam ser tão razoáveis que nem prestassem atenção a tais coisas; ou bem o que se quer dizer é que fica abaixo da dignidade do ser humano importar-se com as possíveis preocupações dos lírios, porque com efeito o ser humano é ser humano e não é lírio. Isto quer dizer: ou tais preocupações são, em si e por si, desarrazoadas, e por isso não vale a pena atentar a elas, independentemente de serem os ingênuos lírios ou os seres humanos racionais as tê-las; ou então a preocupação, essencialmente igual, é outra quando o lírio a tem, que não aquela quando o ser humano a tem, de modo que seja tolo da parte do lírio preocupar-se com tais coisas, mas não seja tolo quando se trate de um ser humano. Com efeito, se os lírios tivessem realmente tais preocupações, e o autor do discurso fosse da opinião de que a preocupação essencialmente igual tivesse grande importância em relação a um ser humano: assim, não seria sabedoria ou solidariedade, mas amor humano a si mesmo, o que poderia falar com tal brevidade e de modo tão frio sobre os coitados dos lírios, de modo tão nobre sobre as pequenas tristezas dos lírios, com tanta distinção ao chamá-las de pequenas tristezas, que não são dignas de atenção. Suposto que fosse então assim, que houvesse diferenças entre os lírios, uns dos outros, que em seu mundo minúsculo correspondessem às diferenças humanas; suposto que estas diferenças ocupassem e preocupassem os lírios, tanto quanto os homens - e suposto então que em verdade fosse verdadeiro o que ficou dito: tais diferenças e tais preocupações não são dignas de atenção.

Vamos meditar sobre este assunto mais de perto; e dado que o preocupado que saiu a ver os lírios no campo, sim, justamente desejando evitar toda comparação com outros homens, dado que tanto o desgostava que algum outro ser humano falasse com ele sobre 
sua aflição; então este discurso há de respeitar sua preocupação; não falarei de um outro ser humano, nem sobre algum ser humano preocupado, mas prefiro falar sobre o lírio preocupado.

Era uma vez um lírio que cresceu num lugar afastado junto a um regato que corria, e era bem conhecido de algumas urtigas, mais um punhado de outras florezinhas na vizinhança. O lírio estava, segundo as verazes palavras do Evangelho, vestido mais formosamente do que Salomão em sua glória, além disso, sem preocupações e alegre enquanto durava o dia. Despercebida e vividamente o tempo passava, como a água corrente do riacho, que cantarolava e desaparecia. Ocorreu, porém, que um dia chegou um passarinho e visitou o lírio, retornou no outro dia, ficou fora vários dias, até que outra vez retornou, o que pareceu ao lírio estranho e inexplicável, inexplicável que o pássaro não permanecesse no mesmo lugar, tal como as florezinhas, estranho que o pássaro pudesse ter tais caprichos. Mas, como ocorre tão frequentemente, ocorreu também com o lírio que justamente por causa disto ele se apaixonasse cada vez mais pelo pássaro, por ter ele tais caprichos.

Este passarinho era um pássaro malvado; ao invés de se colocar no lugar do lírio, ao invés de se alegrar com a sua formosura, e se alegrar com ele em sua felicidade inocente, o pássaro queria fazer-se de importante, sentindo sua liberdade e fazendo o lírio sentir sua amarração. E não só isto, mas o pássaro era também conversador, e contava de coisas soltas e firmes, verdadeiras e falsas, de como em outros lugares havia, em grande quantidade, lírios magníficos totalmente diferentes, onde havia uma alegria e uma animação, um perfume, uma riqueza de cores, um canto de pássaros que excedia toda descrição. Assim contava o pássaro e cada uma de suas narrativas costumava acabar com uma observação que para o lírio era humilhante, de que este, em comparação com tal glória, não era nada, de que era tão insignificante que até se levantava a questão de com que direito ele de fato se chamava lírio.

Assim, o lírio foi ficando preocupado; quanto mais escutava o pássaro, tanto mais preocupado ficava; não mais dormia tranquilo à noite e não mais acordava alegre pela manhã; sentia-se preso e amarrado, achava tedioso o correr da água do regato o dia todo. Começava agora a se ocupar consigo mesmo e com as condições de sua vida em autoaflição - o dia inteiro. "Pode até ser bem bom", dizia ele para si mesmo, "de vez em quando, para variar, escutar o correr da água do riacho, mas entra dia e sai dia ouvir a mesma coisa eternamente: é afinal demasiado enfadonho." "Pode talvez até ser agradável", dizia para si mesmo, "de vez em quando estar num lugar afastado e solitário, mas assim, por toda a vida, ficar esquecido, e estar sem companhia ou na companhia das urtigas ardidas, que afinal não são decerto companhia para um lírio: não dá para suportar." "E então ter uma aparência tão humilde, como no meu caso", dizia o lírio para si mesmo, "ser tão insignificante, como o passarinho diz que eu sou: ah, por que afinal eu não nasci num outro lugar, sob outras circunstâncias? Ah, por que eu não me tornei, afinal, uma coroa-imperial ${ }^{8}$ ?" Pois o passarinho lhe contara que a coroa-imperial era considerada o mais belo entre 
todos os lírios, e era objeto de inveja de todos os outros lírios. O lírio percebeu, decerto, infelizmente, que a preocupação o abalara; mas então falou para si mesmo apelando para a razão, não, porém, com tanta razão que tirasse a preocupação da cabeça, mas de um modo que ele mesmo se convenceu de que a preocupação era correta; "pois", dizia ele, "meu desejo não é, afinal de contas, nenhum desejo desarrazoado, eu não exijo afinal algo de impossível, tornar-me alguma coisa que eu não seja, um pássaro, p. ex.; meu desejo é tão somente tornar-me um lírio glorioso, ou quem sabe até o mais glorioso de todos.”

Enquanto ocorria tudo isso, o passarinho voava para lá e para cá, e a inquietação do lírio era alimentada a cada uma de suas visitas e a cada uma de suas separações. Por fim, ele se confiou inteiramente ao pássaro. Uma hora noturna combinaram que na manhã seguinte aconteceria uma mudança, e pôr-se-ia um fim à preocupação. Na manhã seguinte, bem cedo, veio o passarinho; com seu bico escavou a terra ao redor da raiz do lírio, de modo que assim ele pudesse ficar livre. Tendo sucedido isto, o pássaro tomou o lírio sob sua asa e voou dali embora. Com efeito, a combinação era a de que o pássaro voaria com o lírio para lá onde floresciam os lírios vistosos; depois, o pássaro deveria novamente ajudar a deixá-lo plantado ali, para ver se com a mudança de lugar e o novo ambiente não sucederia ao lírio tornar-se um lírio vistoso na companhia dos outros muitos, ou talvez até uma coroa-imperial, invejada por todos os demais.

Ai, no caminho o lírio ia murchando. Se o lírio aflito se tivesse contentado em ser lírio, não se teria afligido; se não se tivesse preocupado, teria ficado parado lá onde estava - onde estava, em toda a sua formosura, teria aí sido justamente aquele lírio, sobre o qual o Pastor falou no Domingo passado, quando repetia a palavra do Evangelho: "Observai o lírio, eu vos digo que nem Salomão em toda a sua glória vestiu-se como ele”. Pois de outro modo não se pode, afinal, compreender o Evangelho; pelo contrário, é triste, sim, quase horrível, ainda que seja verdade, que um comentador ${ }^{9}$ da Sagrada Escritura, a propósito desta passagem sobre os lírios, se sentisse motivado, tal como o passarinho, a esclarecer: que a coroa-imperial cresce espontaneamente naquelas paragens - como se assim se pudesse compreender melhor que o lírio sobrepujava em formosura Salomão, como se assim se pudesse compreender melhor o Evangelho, que portanto não se adequaria ao lírio não vistoso.

Assim se passou, então, com o lírio preocupado, cuja preocupação estava em se tornar um lírio magnífico ou quiçá uma coroa-imperial. O lírio é o ser humano. O pássaro malvado é o inquieto pensamento da comparação, que vagueia por toda parte, em círculos, inconstante e cheio de caprichos e recolhe o saber malsão da diferença; e tal como o pássaro não se colocou no lugar do lírio, assim a comparação o faz, com ela o ser humano coloca-se no lugar de um outro, ou coloca um outro no seu lugar. O passarinho é o poeta, o sedutor, ou aquilo que há de poético e sedutor no ser humano. O poético é

9 Provável referência ao autor alemão Claus Gratz, que comenta o Evangelho de Mateus especificando o lírio como sendo a coroa-imperial, de vermelho acentuado. (N.T.) 
como a fala do pássaro, verdadeira e falsa, poesia e verdade ${ }^{10}$; pois é verdade que existe a diferença, e que há muito a se dizer sobre ela, mas o poético consiste em que a diferença seja apaixonadamente, no desespero ou no júbilo, o mais elevado, e isto é eternamente falso. Na aflição da comparação, o preocupado vai afinal tão longe que esquece, por causa da diferença, que ele é um ser humano, de modo que desesperadamente acha que é de tal modo diferente de outros homens que quase crê ser diferente daquilo que é ser homem, assim como o pássaro também achava que o lírio era tão pouco vistoso que até surgia a questão se ele seria realmente um lírio. Mas a defesa supostamente razoável da preocupação é sempre esta: de que a gente não exige algo de desarrazoado, tornar-se um pássaro, p. ex., mas apenas tornar-se esta coisa determinada que não se é, mesmo que esta coisa determinada pareça, por sua vez, a outros preocupados como algo puramente insignificante. Quando então a comparação, com o movimento do pássaro para lá e para cá, inflamou a paixão da preocupação e arrancou o preocupado do solo da terra, isto é, do querer ser aquilo a que está destinado: aí parece, por um momento, como se agora a comparação viesse para levar o preocupado ao seu objetivo almejado; mas ela vem, decerto, e o leva, contudo, embora apenas como quando a morte leva um ser humano, faz o preocupado falecer no oscilar do desânimo.

Agora, na medida em que o homem, não sem um sorriso, pode pensar na aflição do lírio por tornar-se coroa-imperial, pode dar-se conta de que este morreu no meio do caminho: oh, aí reflita o homem que pelo contrário seria de se lamentar se um ser humano se afligisse por coisas assim tão desarrazoadas; tão desarrazoadas assim, mas não, como me atreveria a deixar as coisas assim em suspenso, como ousaria assim seriamente mirar os mestres divinamente indicados: os lírios no campo? Não, o lírio não se preocupa desta maneira, justamente por isso devemos aprender dele. E quando então um ser humano, tal como o lírio, contenta-se com ser homem, aí ele não adoece de preocupação temporal; e quando não se preocupa temporalmente, aí fica naquele lugar que lhe foi indicado; e quando ali permanece, aí é verdade completa também, que ele, ao ser homem, é mais glorioso do que a glória de Salomão.

O que aprende dos lírios, portanto, o preocupado? Ele aprende a se contentar em ser homem, e a não se afligir com a diferença entre um homem e outro; aprende a falar com a mesma brevidade, com a mesma solenidade, com a mesma elevação, sobre ser homem como o Evangelho fala com brevidade sobre os lírios. E esta é afinal, por certo, também a maneira humana empregada nas ocasiões mais solenes. Pensemos em Salomão. Quando ele se veste com a púrpura real, quando senta de modo majestoso ao trono em toda a sua glória: aí sim, aí se pode falar de um modo tão solene, que o orador até diz: Vossa Majestade; mas quando, na linguagem eterna da seriedade, se há de falar com a mais alta solenidade, aí o que se diz é: Homem! E justamente o mesmo dizemos nós para o mais humilde de todos, quando ele, como Lázaro, jaz quase irreconhecível na

10 Alusão ao título da autobiografia de Goethe. (N.T.) 
pobreza e na miséria, dizemos: Homem! E no momento decisivo para uma vida humana, quando se oferece a eleição da diferença, nós lhe dizemos: Homem! E no momento decisivo da morte, quando todas as diferenças são abolidas, dizemos: Homem! Contudo, assim não falamos de um modo inferior, pelo contrário, dizemos o mais elevado, porque isto de ser homem não é inferior às diferenças, mas é superior a elas; pois aquela glória essencialmente igual entre todos os seres humanos não é, contudo, a triste igualdade da morte, tão pouco como a igualdade essencial entre todos os lírios, que afinal é justamente a igualdade na formosura.

Toda preocupação mundana tem seu motivo ou razão no fato de que um homem não quer contentar-se em ser um homem, no fato de que pela comparação seu desejo aflito orienta-se para a diferença. Da preocupação terrena e temporal, pelo contrário, a gente não se atreve a dizer diretamente e sem mais que esta seria uma invenção da comparação, pois que um homem, no verdadeiro instante do aperto ${ }^{11}$, necessita de alimentos e de roupas, isto ele não inventa pela comparação. Aquele que vivesse solitário entre os lírios do campo também o descobriria. A preocupação com a alimentação, ai, ou como mais usualmente é chamada num triste plural, as preocupações com a alimentação, não são diretamente uma invenção da comparação. Uma outra coisa é quando de incontáveis maneiras a comparação trabalha de modo ambíguo com as definições do que se deveria entender por preocupação com a alimentação, se acaso não teria de ser, afinal... mas não, o preocupado não quereria, afinal, justamente para evitar a comparação, que algum outro homem lhe viesse falar sobre isto; pois bem, formulemos então assim: se não se deveria poder aprender bastante dos pássaros a respeito desta preocupação.

Eis o que queremos observar agora: como é que aquele a quem o cuidado com a alimentação causa preocupação, ao prestar atenção corretamente às aves do céu aprende a contentar-se em ser homem.

"Olhai as aves do céu." Olhai para elas, quer dizer, atentai exatamente para elas; assim o pescador chega pela manhã e examina a linha que à noite ele lançara ao mar; assim chega o médico e examina o enfermo; assim a criança se detém e examina quando o adulto faz algo que ela nunca tinha visto. Assim se deve, não com a mente dividida e os pensamentos dispersos, mas com atenção e reflexão concentradas, se possível com admiração, atentar detidamente aos pássaros. Se alguém dissesse: Um pássaro a gente já viu tantas vezes, não há por certo, afinal de contas, nada de notável: então este não compreendeu o convite do Evangelho sobre os pássaros do céu. - "Os pássaros do céu”, ou, como é dito num outro lugar, "os pássaros debaixo do céu”. Pois é claro que a gente também vê pássaros no solo, a gente os vê no chão, mas se devemos tirar bom proveito de observá-los, temos que olhá-los debaixo do céu, ou contudo recordar constantemente na imaginação que a moradia deles é debaixo do céu. Se alguém pudesse, ao ver frequentemente um pássaro no solo, esquecer que ele era um pássaro do céu, ter-se-ia impedido a si mesmo de compreender o Evangelho sobre as aves do céu. - "Não semeiam, nem colhem, nem ajuntam em celeiros." Como

11 Trangens: do apuro, da necessidade. 
poderiam acontecer tais coisas, onde os pássaros têm seu refúgio - debaixo do céu, lá onde vivem sem a prevenção ${ }^{12}$ da temporalidade, desconhecendo o tempo, no instante? O homem prevenido sobre a terra aprende do tempo a utilizar o tempo, e quando a partir de um tempo passado ele tem o celeiro lotado, e está precavido para o tempo presente, aí ele cuida de plantar de novo para uma colheita futura, para que outra vez venha a ter o celeiro cheio para um tempo futuro. Por isso se utilizam ali três palavras para designar o trabalho da prevenção; não se diz brevemente, como sobre os lírios: eles não trabalham; com as três palavras indica-se a determinação do tempo que se situa na base da prevenção. - "E no entanto vosso Pai celeste as alimenta." O Pai celeste, sim, é evidente, tem de ser Ele, já que o observador olha para as aves - debaixo do céu; pois lá, aonde o camponês vai de manhã, ao meio dia e à tarde e chama as aves, reunindo-as e as alimenta: lá o observador pode facilmente equivocar-se e acreditar que é o camponês quem alimenta as aves. Mas lá onde não existe nenhum camponês - no campo aberto, lá onde não há nenhuma despensa - debaixo do céu, lá onde as aves despreocupadas, sem semear, sem colher, sem juntar no celeiro - e sem preocupações com a alimentação voejam leves sobre os bosques e os lagos: lá, afinal, tem de ser por certo o Pai celeste quem as alimenta. "Ele as alimenta"; ou deveríamos dizer, talvez, tolamente, o que decerto muito camponês tolo já disse: "as aves roubam", deste modo quem alimenta as aves é propriamente o camponês, porque essas de fato roubam dele. Ai, se um pensamento humano mergulhasse tão fundo na baixa miséria que, em seriedade contrariada, ele chegasse a pensar uma tal coisa: como poderia então aprender a elevação das aves do céu, como é que isto poderia ajudá-lo a examinar as aves do céu? E no entanto, isto deveria com certeza auxiliá-lo, caso simplesmente quisesse olhar para elas, ou seja, atentar detidamente para elas, tornar a aprender ${ }^{13}$, aprender a esquecer o senso comum rasteiro que, de forma desumana, tornou sua alma mesquinha. Não, o Pai celeste alimenta as aves, e isto a despeito de que elas não semeiam, nem colhem, nem ajuntam em celeiros, quer dizer, é o Pai celeste quem alimenta também as criaturas que semeiam e colhem e ajuntam nos celeiros, e por isso aquele que alimenta a si mesmo deve aprender dos pássaros que é, afinal de contas, o Pai celeste quem o alimenta. Mas aquele que nada, simplesmente nada possui na terra; aquele que assim - igualmente vive "debaixo do céu"; aquele que com tristeza percebe que está muito próximo no - alegre parentesco com os pássaros do céu: aprende que é o Pai celeste que os alimenta.

"Olhai as aves do céu - vosso Pai celeste as alimenta." Quão breve, quão solene, quão igualitário é este discurso. Fala-se de todas as aves, nem uma única é esquecida no discurso que explica que o Pai celeste jamais esquece de uma única dessas, Ele, que abre sua mão suave e sacia tudo o que vive à vontade ${ }^{14}$. No discurso do Evangelho sobre os pássaros não se menciona nem um pouco alguma diferença; que um deles talvez recebesse abundantemente, o outro parcamente; um deles talvez provisão por um tempo um pouco

12 Forsynlighed: precaução.

13 lare om igjen: revisar os conceitos.

14 Salmos 145, 16. 
mais longo, o outro somente o necessário para o momento; que uma vez ou outra um deles teve de esperar, esperar em vão, teve de talvez deitar-se faminto: não, apenas se fala sobre as aves e de que o Pai celeste as alimenta.

Contudo, talvez alguém diga: "Ainda que um pássaro de vez em quando recebesse de menos, ainda que aí também morresse um pássaro de fome, a coisa por certo não seria assim tão grave". Como é que deste modo um homem poderia ter um coração para falar assim sobre os pássaros? A preocupação pelo sustento não é e será sempre essencialmente a mesma, quer seja a ave que a tenha, quer seja o homem? Deveria o homem, altivo, desdenhar esta preocupação, se fosse apenas o pássaro quem a tivesse, e o homem estivesse livre dela? Ou seria desarrazoado da parte do pássaro preocupar-se com tais insignificâncias, mas não seria desarrazoado da parte do homem racional preocupar-se com as mesmas insignificâncias? Suponhamos que a vida do pássaro não deixasse de conhecer esta diferença no que se refere ao sustento, a qual se faz valer tanto pior entre os homens; suponhamos que esta diferença ocupasse e preocupasse as aves da mesma maneira como preocupa o homem.

Da mesma maneira - quando se admite isto, aí o discurso pode afinal evitar, aquilo que ao preocupado tanto desagradaria, que um outro homem lhe falasse sobre a preocupação dele, de modo que o discurso pode permanecer lá fora no campo junto aos pássaros e conversar sobre a preocupação do pássaro.

Era uma vez uma pomba do mato; lá onde a admiração habita junto com o calafrio, em meio aos troncos aprumados e isolados, esta tinha o seu ninho. Próximo dali, porém, lá onde a fumaça se eleva da casa do camponês, moravam alguns de seus parentes mais distantes: algumas pombas domésticas. Com um par dessas ela seguidamente se encontrava; com efeito, assentava-se sobre um galho que se inclinava por cima da quinta do camponês; as duas pombas domésticas assentavam-se na cumeeira do telhado, mas a distância não era tão grande que as impedisse de trocarem opiniões, entre si, numa conversa. Um belo dia, conversavam sobre assuntos dos tempos e sobre o sustento. A pomba do mato dizia: "Eu tenho tido até agora, de um jeito ou de outro, o meu sustento, deixo a cada dia suas dificuldades, e deste modo vou avançando pelo mundo”. As pombas mansas escutaram com atenção, não sem experimentarem uma certa emoção voluptuosa perpassar todo o corpo, a que se chama pavonear-se, depois responderam: "Não, aí nós procedemos de outro modo; no nosso caso, isto é, na casa do rico camponês com quem vivemos, a gente tem o futuro assegurado. Quando chega o tempo da colheita, então eu me sento, ou o meu esposo, um dos dois se assenta lá em cima do telhado e observa. Então o camponês vai trazendo, uma depois da outra, carradas de grãos, e quando ele assim carregou para dentro tantas que eu nem consigo mais contar, aí sei que há provisão suficiente para muito tempo, e o sei por experiência”. Logo que terminou de falar assim, voltou-se, não sem um certo amor-próprio ${ }^{15}$, para seu esposo, assentado junto a ela, como se dissesse: "Não é verdade, maridinho? Nós dois temos o nosso garantido”.

15 Selvfolelse: autoconfiança. 
Quando a pomba do mato foi para seu lugar, refletiu mais de perto sobre aquele assunto; prontamente lhe ocorreu que deveria ser uma grande comodidade saber, desta maneira, que se tinha o sustento garantido por longo tempo, e ao contrário era miserável viver assim constantemente num rumo incerto, de modo que jamais se ousasse dizer que a gente sabe que está provido. Por isso seria então melhor, pensou consigo mesma, que tu experimentasses, para ver se não conseguirias recolher uma provisão maior, que poderias deixar colocada num ou noutro lugar bem seguro.

$\mathrm{Na}$ manhã seguinte ela despertou mais cedo do que de costume e teve tanta trabalheira para recolher que quase nem teve tempo para comer ou para se alimentar bastante. Mas era como se uma fatalidade pairasse sobre ela, como se não lhe fosse permitido juntar prosperidade, pois cada vez que tinha reunido uma pequena provisão e a escondido num ou noutro lugar supostamente seguro - quando voltava para conferir, já havia desaparecido. Neste ínterim, não ocorreu nenhuma mudança essencial em relação ao sustento, ela encontrava cada dia o seu alimento do mesmo modo como antes, e à medida que se tornava mais escasso para ela, isso acontecia porque ela queria juntar e porque nem se dava tempo para se alimentar, pois caso contrário ela teria o sustento tão abundante como antes. Ai, e contudo ocorreu-lhe uma grande mudança, ela não sofria de nenhuma carência real, mas tinha assumido uma noção de carência para o futuro, havia perdido sua tranquilidade - agora tinha preocupação com alimentação ${ }^{16}$.

Desde então a pomba do mato ficou aflita ${ }^{17}$, suas penas perderam o brilho da cor, sua fuga ${ }^{18}$ perdeu a leveza; seu dia passava numa tentativa infrutífera de juntar prosperidade $^{19}$, seus sonhos eram os planos impotentes da imaginação; não estava mais alegre, estava sim quase invejosa das pombas ricas; encontrava seu alimento todo dia, satisfazia-se, e contudo parecia que não ficava satisfeita, porque passava fome por longo tempo ao se preocupar com o alimento; ela se aprisionara a si mesma naquela armadilha, na qual nenhum caçador de pássaros podia retê-la, na qual somente aquele que é livre pode aprisionar-se a si mesmo: na representação. "É bem verdade", dizia para si mesma, "é bem verdade que quando cada dia eu consigo tanto quanto sou capaz de comer, aí eu tenho o meu sustento; a grande provisão que desejo juntar eu não poderia comer de uma só vez, e em certo sentido a gente não pode mais do que se fartar; seria, porém, uma grande comodidade ser liberado desta incerteza, pela qual a gente se torna tão dependente." "Pode bem ser", dizia para si mesma, "que as pombas domésticas comprem caro o seu sustento garantido; pode bem ser que elas, no fundo, tenham muitas preocupações, das quais eu até agora estava liberada, mas este asseguramento do futuro paira constantemente diante

16 Naringssorg: preocupação econômica.

17 bekymret: preocupada.

18 dens Flugt: seu voo.

19 Velstand: riqueza. 
de minha cabeça; ah, por que eu fiquei afinal uma pobre pomba do mato e não uma das pombas ricas?" Assim ela ainda percebeu que a preocupação esgotava suas forças, mas aí ela falou para si mesma de um modo razoável, contudo não tão razoável que expulsasse a aflição de seu pensamento, e levasse sua mente ao repouso ${ }^{20}$, mas de tal modo que ela se convenceu de que a preocupação era correta. "Eu não exijo afinal nada de desarrazoado", dizia ela, "ou algo de impossível, afinal eu não exijo tornar-me como o camponês rico, mas apenas como uma das pombas ricas."

Por fim, ela imaginou uma artimanha. Um dia voou para lá e se assentou na cumeeira do telhado do camponês entre as pombas mansas. Quando ela depois se deu conta de que havia um lugar, para dentro do qual essas voavam, voou também para dentro, pois ali devia decerto estar a despensa com as provisões. Mas quando ao anoitecer veio o camponês e fechou o pombal, ele prontamente descobriu a pomba desconhecida. Esta foi depois depositada numa pequena gaiola só para ela até o dia seguinte, quando então foi morta - e libertada das preocupações com alimentação. Que pena, a preocupada pomba do mato não apenas se havia aprisionado a si mesma na preocupação, mas também se aprisionara a si mesma no pombal - para a morte.

Se a pomba do mato se tivesse contentado em ser o que ela era: uma ave do céu, então ela teria tido seu sustento, então o Pai celeste a teria alimentado, então ela teria, nas condições da incerteza, permanecido lá onde ela pertencia, lá onde os troncos eretos e isolados melancolicamente combinam com o gorjeio arrulhante da pomba do mato; então ela teria sido aquela sobre a qual o Pastor falava no Domingo, quando repetia a palavra do Evangelho: Olhai as aves do céu, elas não semeiam nem colhem nem ajuntam em celeiros, e no entanto o vosso Pai celestial as alimenta.

A pomba do mato $^{21}$ é o ser humano - mas não, não nos esqueçamos de que o discurso, apenas por deferência para com o preocupado, utilizou a pomba do mato como exemplo. Sim, tal como quando uma criança da mais alta nobreza está sendo educada e uma criança pobre é mantida por perto para receber os castigos no lugar do príncipe: foi assim que o discurso jogou tudo sobre a pomba do mato. E esta o aceitou de boa vontade, pois sabe muito bem que ela é um daqueles mestres incumbidos por Deus, dos quais nós devemos aprender; mas tais coisas um mestre também faz, de vez em quando, ao mostrar em si mesmo a coisa errada, contra a qual ele quer advertir. A pomba do mato, ela mesma, não tem tais cuidados ${ }^{22}$, ela é realmente aquela de quem fala o Evangelho. - Portanto, a pomba do mato é o ser humano. Quando ele, como aquela, contenta-se em ser um homem, então entende o que aprende do pássaro do céu, que o Pai celeste o alimenta. Mas se o Pai celeste o alimenta, aí ele fica afinal sem preocupação com o sustento, dado que

20 til Ro: para a calma, a tranquilidade.

21 Skovduen: pomba-rola.

22 er sorglos: vive desafogada. 
ele não habita meramente, como as pombas domésticas, junto ao rico camponês, mas habita junto Àquele que é mais rico do que todos. Ele habita realmente junto a Ele, pois dado que o céu e a terra são a casa e a propriedade de Deus, então o ser humano mora, de fato, junto a Ele.

Ou seja: contentar-se em ser um homem, contentar-se em ser o humilde, a criatura, que tão pouco é capaz de se sustentar a si mesma, como de criar a si mesma. Mas se pelo contrário o ser humano quer esquecer Deus - e alimentar-se a si mesmo; então temos a preocupação com o sustento. É decerto louvável e agradável a Deus que um homem plante e junte e recolha no celeiro, que trabalhe para encontrar o alimento; mas se vier a esquecer Deus e achar que com seu trabalho vai alimentar a si mesmo, então ele terá preocupação com o sustento. O homem mais rico de todos os que já existiram, caso se esqueça de Deus e ache que se alimenta a si mesmo; tem, também ele, preocupação com o sustento. Pois não vamos falar de maneira tola e mesquinha, dizendo que o rico está livre da preocupação com o sustento, e o pobre não. Não, somente está livre aquele que, contentando-se em ser homem, compreende que o Pai celeste o alimenta; e disto é capaz tanto o pobre quanto o rico.

Preocupação com o sustento [econômica] é por isso a armadilha na qual nenhum poder exterior, nenhuma realidade efetiva é capaz de aprisionar um ser humano, porém na qual somente ele é capaz de aprisionar a si mesmo, o rico tão bem quanto o pobre - logo que não se contenta em ser um homem. Com efeito, quando ele não quer contentar-se com isso, o que é então o mais que ele exige? O mais é: ser ele mesmo sua própria providência para toda a vida, ou quiçá apenas para o dia de amanhã; e quando ele o quer, então ele entra - engenhosamente - na armadilha, o rico, tão bem quanto o pobre. Deste modo, ele quer, por assim dizer, colocar um muro ao redor de si, numa mancha de terra pequena ou grande, que não deva ser objeto da providência de Deus e dos cuidados sustentadores do Pai celestial. Talvez não perceba, antes que seja demasiado tarde, que nesta segurança entrincheirada ele mora, de fato, numa prisão. Ele mesmo faz aquilo que o camponês fez com a pomba do mato, ele próprio tranca a gaiola, e crê que agora está seguro, e agora está justamente aprisionado, ou, o que pode ser expresso também de uma outra maneira, agora está excluído dos cuidados da Providência e deixado à mercê da preocupação com o sustento. Pois só está aprisionado e excluído aquele que se encerrou ${ }^{23}$ nos seus bens, muitos ou poucos, achando que se alimentava a si mesmo; e só é livre e sem preocupação de sustento aquele que com muitos ou com poucos bens, sim, mesmo na penúria, compreende que o Pai celeste o alimenta. E esse que num entendimento atrevido engenhosamente se trancou a si mesmo nestas coisas e com estas coisas se aprisionou, esse, justamente, tal como a pomba do mato, em sentido espiritual, aprisionou-se a si mesmo, [condenado] à morte.

Já desta maneira se evidencia que preocupação com o sustento surge pela comparação; aqui, com efeito, mostra-se de um modo terrível que o homem não quer contentar-

23 udelukket: excluído; lukeket inde: encerrado. 
-se em ser homem, mas quer comparar-se com Deus, quer ter uma segurança graças a si mesmo, como a nenhum homem é permitido ter, segurança esta que por isso é justamente - a preocupação com o sustento.

Mas também de outras maneiras se mostra que a preocupação com o sustento surge pela comparação, ou seja, na medida em que a preocupação com o sustento não é a necessidade real do dia de hoje, mas sim a representação de uma futura. Surge outra vez a comparação pelo fato de o homem não querer contentar-se em ser homem. A pobre ave do céu se comparava com as aves ricas; por causa desta comparação ela descobria a preocupação com o sustento. O que significa ter fome e achar alimento, isto ela já sabia desde muito tempo, mas preocupação com o sustento antes ela não havia tido. E então estas determinações: rico e pobre, não estavam separadas entre si por um abismo escancarado, dado que elas, pelo contrário, se tocam mutuamente no convívio contínuo e em constante conflito fronteiriço, e aí além disso as diferentes perspectivas modificam mais ou menos a determinação: assim pode também ser o terceiro da comparação o mais extremamente diferente. $\mathrm{Na}$ preocupação com o sustento não quer então o preocupado contentar-se em ser homem, mas quer ser ou ter a diferença, quer ser rico, afortunado, abastado, de alguma maneira assegurado, e assim por diante. Ele não observa, com efeito, as aves do céu - afastadas da diversidade da vida humana, mas olha para os outros comparando-se, olha para a diversidade, e sua preocupação com o sustento é uma relação de comparação.

E ainda que o preocupado não fixe desta maneira sua atenção sobre a diferença de graus e chame de preocupação com o sustento isto, que é antes aflição mundana (pois afinal de contas isto não é preocupação com o sustento, preocupar-se com possuir tanto quanto este ou aquele), ainda que não seja este o caso, encontra-se contudo uma comparação na base da preocupação com o sustento, na medida em que esta não é a expressão para a necessidade real, mas sim imaginada. De onde provém que o pássaro não tenha preocupação com o sustento? Do fato de ele não comparar um dia com o outro, e de acordo com a palavra do Evangelho deixar a cada dia a sua dificuldade. Mesmo, porém, que o preocupado não compare sua condição com a de um outro homem, e neste sentido "se mantenha puro deste mundo" (ai, a comparação é talvez uma das mais corrompidas espécies de mácula) - quando contudo ansiosamente compara um dia com o outro, se num dia em que teve ganho abundante diz: Mas amanhã? E se no dia em que tem pouco ele diz: Amanhã será ainda pior: assim está ele comparando! Ai, se um tal preocupado lesse isto, oxalá não se impacientasse com o palestrante. De bom grado eu faria como fez um sábio pagão por deferência ao objeto do discurso: cobria seu rosto; de bom grado eu faria assim por respeito à preocupação, cobriria minha face, de modo a não ver ninguém, e falaria sobre a ave do céu. Foi afinal devido a esta espécie de comparação que a pomba do mato no convívio preocupado da aflição consigo mesma de um dia para o outro descobriu a preocupação com o sustento; admitiu, afinal, que ela tinha o seu ganho, mas a insegurança a entristecia, parecia que ficava muito dependente - de Deus. Causava-lhe desgosto que jamais pudesse falar com segurança sobre o próximo dia - ó, mas não nos 
esqueçamos de que ela podia sim num sentido divino falar com segurança, se ela dissesse: O Pai celeste me alimentará bastante amanhã; não nos esqueçamos de que falaria com a maior de todas as seguranças sobre o dia de amanhã se ela se limitasse com muita interioridade a apenas agradecer pelo dia de hoje! As coisas não são assim? Se acaso houvesse uma jovem apaixonada, a quem o amado viesse e visitasse, e se acaso aí ela lhe dissesse: Voltas então de novo amanhã? Neste caso haveria alguma aflição em seu amor. Mas se ela, sem nomear o dia de amanhã, se jogasse em seus braços e dissesse: Ó, obrigada por teres vindo hoje: então ela estaria bem tranquila pelo dia de amanhã. Ou, caso houvesse duas jovens, e uma delas dissesse ao seu amado: Volta então amanhã outra vez; e a outra dissesse: Ó, obrigada por teres vindo hoje: qual destas duas estaria mais convencida de que seu amado haveria de retornar no dia de amanhã?

No mundo, bem frequentemente, leva-se adiante a inútil e talvez vã discórdia, quando o pobre diz ao rico: Sim, para ti é fácil, estás livre da preocupação com o sustento. Quisera Deus, porém, que o pobre pudesse compreender direito o quanto o Evangelho quer o que é muito melhor para este: igualitária e mais amorosamente. $\mathrm{Na}$ verdade, o Evangelho não se deixa encantar pela ilusão sensorial da diferença visível, não se deixa enfeitiçar a tomar partido por algum homem contra algum outro homem, com o rico contra o pobre ou com o pobre contra o rico. O não ter preocupação com o sustento é em verdade uma coisa agradável aos olhos de Deus: teria então decerto o rico, sem mais nem menos, esta vantagem, e o pobre estaria excluído dela? Ai, não. Se o pobre se contentasse mesmo em ser um homem, e aprendesse das aves do céu a não se preocupar com o sustento, então ele poderia elevar-se com simplicidade por sobre a diferença aparente, ele talvez se sentisse de vez em quando motivado a dizer: Coitado do rico, afinal, este sim tem preocupação com o sustento. Pois qual é o homem que pode dizer, com razão e com verdade, estas palavras: Eu não tenho nenhuma preocupação com o sustento? Se o rico, ao dizê-lo, aponta para as suas riquezas: será que há vestígios de sentido em sua fala? Não se contradiz no mesmo instante, de forma que clama aos céus, ele, que se atém à preocupação com o sustento, enquanto a mantém afastada com seus tesouros e por preocupação com o sustento os vigia e os aumenta? Sim, se o rico abandonasse todos os seus bens, lançasse para longe de si dinheiros - e preocupações com o sustento, e dissesse: Eu não tenho preocupação com o sustento; só então haveria afinal sentido em seu discurso. E este é, de fato, o caso do pobre, quando ele, que nada possui e neste sentido nada tem para jogar fora, joga a preocupação com o sustento para cima de Deus e diz: Eu não tenho nenhuma preocupação com o sustento. Não é desta maneira que as riquezas têm de ser afastadas, se é que deveria haver algum sentido, pelo menos, no discurso? Se alguém que possuísse uma dispendiosa coleção de esplêndidos medicamentos, dos quais tomasse alguma coisa todo dia, quisesse, apontando para os remédios, dizer: Eu não estou doente! - não seria esta uma gritante contradição?

Com bastante frequência leva-se adiante no mundo, entre uns e outros homens, o insatisfeito conflito da comparação sobre dependência e independência, sobre a sorte 
que há em ser independente e o pesado que é ser dependente. E no entanto, no entanto, jamais a linguagem humana e jamais o pensamento descobriram um símbolo mais belo para a independência do que - o pobre pássaro do céu; e contudo, contudo, nenhum discurso pode ser mais estranho que o de que fosse tão pesado ser - leve como o pássaro! Ser dependente de seus tesouros, isto é dependência e pesada servidão; ser dependente de Deus, totalmente dependente, isto é independência. A preocupada pomba do mato temia tolamente ficar de todo dependente de Deus, por isso cessou de ser independente e de ser um símbolo da independência, deixou de ser a pobre ave do céu, que é totalmente dependente de Deus. Dependência de Deus é a única independência, pois Deus não tem peso, só o têm o terreno e especialmente os tesouros terrenos; aquele, então, que é de todo dependente Dele, é leve. Assim ocorre com o pobre, quando ele, contente em ser homem, observa a ave do céu, observa-a - debaixo do céu, para o qual olha sempre aquele que está orando, o suplicante ${ }^{24}$, não, este, o independente, é na verdade um gratulante ${ }^{25}$.

Contentar-se em ser homem. Era disto que tratava este discurso, e de como o preocupado o aprende dos lírios do campo e das aves do céu, e de como, em contraste, a comparação engendrou a aflição terrena, e de como ela engendrou o cuidado com o sustento. É claro que foi um homem quem discursou, mas, apoiado pelos lírios e pelas aves, ele falou sobre os lírios e as aves. E assim, o fato de ele ser o orador não implica em nenhuma comparação com algum outro ser humano, como se aquele tivesse alguma vantagem por ser orador; não, aqui volta a imperar a igualdade frente a frente ${ }^{26} \mathrm{com}$ os mestres divinamente nomeados: os lírios do campo e as aves do céu.

24 den Bedende: o orante, um que está a pedir.

25 en Takkende: um que agradece, que dá graças.

26 ligeoverfor: vis-à-vis. 